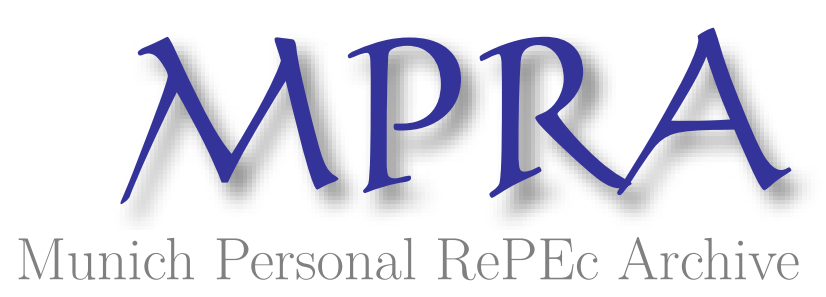

\title{
Social expenditure and poverty reduction in the EU15 and other OECD countries
}

Caminada, Koen and Goudswaard, Kees

Department of Economics, Leiden University

2009

Online at https://mpra.ub.uni-muenchen.de/20138/

MPRA Paper No. 20138, posted 27 Jan 2010 00:25 UTC 
Leiden Law School

Department of Economics Research Memorandum 2009.02

Social Expenditure and Poverty Reduction in the EU15 and other OECD Countries

Koen Caminada and Kees Goudswaard 


\section{Correspondence to}

Leiden Law School

Department of Economics

P.O. Box 9520

2300 RA Leiden

The Netherlands

Phone ++31 715277756

Email: economie@ law.leideniniv.nl

Website: www.economie. leidenuniv.nl

\section{Editors}

Prof. dr. C.L.J. Caminada

Dr. B.C.J. van Velthoven 


\title{
SOCIAL EXPENDITURE AND POVERTY REDUCTION IN THE EU15 AND OTHER OECD COUNTRIES *
}

\author{
Koen Caminada \\ Leiden Law School \\ Economics Department, Leiden University \\ P.O. Box 9520, 2300 RA, The Netherlands \\ URL: www.hsz.leidenuniv.nl \\ E-mail: c.l.j.caminada@law.leidenuniv.nl
}

\author{
Kees Goudswaard \\ Leiden Law School \\ Economics Department, Leiden University \\ P.O. Box 9520, 2300 RA, The Netherlands \\ URL: www.hsz.leidenuniv.nl \\ E-mail: k.p.goudswaard@law.leidenuniv.nl
}

\begin{abstract}
The European Union coordinates and encourages Member State actions to combat poverty, and to reform their social protection systems on the basis of policy exchanges and mutual learning ('best practices'). Some EU countries are more effective in poverty reduction than others. What can explain these variations in effectiveness? This paper analyzes the effectiveness of social transfers in alleviating poverty. We focus on EU15 countries, but also include other OECD countries in our analysis. We compare poverty rates at the levels of market and disposable incomes, that is before and after transfers, in order to analyze the effect of tax and transfer policies in reducing poverty, i.e. to determine the target efficiency of social transfers. We perform several tests with the most recent data (LIS, OECD, SOCX, and Eurostat: ECHP/EU-SILC). Finally, we perform several partial analyses by disaggregating poverty rates to socioeconomic and demographic conditions in order to investigate to what extent variations at the social program level (such as old age pensions, child benefits) affect the measured effectiveness of the welfare state in alleviating poverty.

Empirical results draw heavily on how pensions are treated - as primary income or as transfer. We find a strong relationship between levels of social spending and antipoverty effects of social transfers and taxes across EU15 countries. Social spending seems to be an important determinant of a country's poverty outcome, especially among the elderly, when pensions are considered as transfers. Our analysis highlights some cross-country differences in targeting of social expenditures on poverty alleviation in EU15 and non-EU15 countries around 2005. We introduce an indicator of Public Policy Effectiveness on Poverty Alleviation across countries. Each percentage point of social expenditure alleviates poverty in both EU15 and non-EU15 countries by .7 percentage points on average. Relatively high scores in EU15 countries are found for Ireland and Scandinavian countries, while Italy, Greece and Spain score lowest. Outside Europe the poorest scores are reported for Korea and the USA. Country ranking appears to be rather stable over time when outcomes for 1995 and 2005 are compared, although some of our results may be sensitive to cyclical factors. Finally, we analyzed poverty among vulnerable age groups. Our results show that family programs and child support alleviate poverty among children to a large extent, especially in non-EU15 countries. For public and private old age pension and survivors schemes we find no effect on poverty in case pensions are considered as transfers (both in EU15 and non-EU15 countries). However, this picture changes completely when pensions are counted as transfers. In that case the poverty rate among elderly in EU15 falls from 90 to 21 percent through taxes and social transfers!
\end{abstract}

JEL-codes: H53, H55, I32

Keywords: poverty, welfare states, Lisbon objectives, social indicators

\footnotetext{
Revised version of a paper presented at the 66th International Atlantic Economic Conference, Montreal, Canada, October $11^{\text {th }} 2008$, at the Nake Research Day, Utrecht, October $24^{\text {th }} 2008$, at a seminar of the Institute of Research on Poverty, Madison, May $14^{\text {th }}, 2009$, and at the $16^{\text {th }}$ International Research Seminar on Issues in Social Security Social Security, Poverty and Exclusion in Rich and Poor Countries, FISS, Sigtunahöjden, Sweden, June $18^{\text {th }}$, 2009. We thank John Beirne, Ross Gittell, Bob Haveman, Ferry Koster, Henk Nijboer, Tim Smeeding, Ben van Velthoven, Olaf van Vliet, Cok Vrooman and Barbare Wolfe for useful comments on an earlier drafts and presentations of this paper. This study is part of the research program 'Reforming Social Security'. Financial support of Stichting Instituut GAK is gratefully acknowledged.
} 



\section{INTRODUCTION}

Poverty alleviation has been a European objective already since the Treaty of Rome in 1957. In 2000 the European Council adopted the goal that besides economic growth social cohesion should be strengthened in the EU (the Lisbon Agenda). The open method of coordination was introduced as the means of spreading best practices and achieving greater convergence towards the main EUgoals. Social indicators were developed to monitor the improvements with respect to social cohesion.

The Lisbon Agenda has renewed the interest in poverty alleviation across member states. However, still a sizable proportion of the EU15 population lives in poverty (17 percent), although both poverty structure and poverty rates vary across countries from 10 percent in the Netherlands to about 20 percent in Greece, Italy and Spain. Moreover, the average at-risk-of-poverty rates - an official EU social cohesion indicator - even have risen since the adoption of the Lisbon Agenda.

Some EU15 countries are more effective in poverty reduction than others. What can explain these variations in effectiveness? Obviously, a range of policy strategies may be chosen to tackle poverty, including improving educational outcomes, improving job opportunities and stimulating labor force participation and reducing inequalities in health outcomes.

This paper analyzes the effectiveness of income transfer policies in EU15 countries in alleviating poverty. ${ }^{1}$ To indicate whether European economic integration may have had any impact on poverty reduction, we also include several non-EU15 countries in our analysis as a benchmark. We compare poverty rates at the levels of market and disposable incomes, that is before and after taxes and social transfers, in order to analyze the effect of tax and transfer policies in reducing poverty, i.e. to determine the target efficiency of social transfers. We will perform several tests with data from LIS, OECD, SOCX and Eurostat (ECHP/EU-SILC) and confront our results with earlier findings on cross-country poverty research. This kind of cross-country comparisons may guide us to crosscountry differences on poverty alleviation in the EU15. Finally, we will perform several partial analyses by disaggregating poverty rates to socioeconomic and demographic conditions in order to investigate to what extent variations at the social program level (such as old age pensions, child benefits) affect the measured effectiveness of the welfare state in alleviating poverty.

The paper is organized as follows. In section 2, we discuss the effect of Europeanization of social policies on poverty alleviation. In section 3 we present the research design. Next (section 4), we turn to the reduction of poverty rates through taxes and transfers and its relationship to welfare state effort. Finally (section 5), we look at two vulnerable age groups: children and the elderly. We present linkages across countries of their poverty rates with expenditures for several social programs such as family and child benefits, and public and private old age pensions and survivor schemes. Section 6 closes the paper.

\section{POLICY ON POVERTY ALLEVIATION}

\subsection{Europeanization of social policies}

Member states of the EU are still autonomous when it comes to the design and generosity of their social protection systems. Still, member states have accepted a certain degree of commitment in terms of social protection. This commitment is embodied in two recommendations accepted by the European Council in 1992. The first recommendation, of June 1992, dealt with common criteria concerning sufficient resources and social assistance in social protection systems (92/441/EEC). The second recommendation, of July 1992, addressed the "convergence of social protection objectives and policies" (92/442/EEC). The motivation was that convergence seeks to guarantee the continuation and stimulate the development of social protection within the context of the completion of the internal market. And also, that member states face common problems, such as ageing of the population, unemployment, changing family structures and poverty; common objectives must act as pointers to the way social protection systems are modified to take account

1 The paper of Beblavy (2009) analyses social protection expenditure and poverty profiles for the new EU member states. 
of these problems.

A new and important step was taken at the European Council in Lisbon 2000. For the EU, the strategic goal was set that is become the most competitive and dynamic knowledge-based economy with sustainable economic growth and greater social cohesion before (the decade ending in) 2010. The economic and social agendas were thus explicitly coupled. To achieve these aims, the social model needs to be modernized. To ensure long-term sustainability of the social security systems in the light of the ageing process, participation rates should be increased.

The Treaty of Nice of 2001 took the social agenda further. It was agreed to advance social policy on the basis of the open method of coordination, first employed with respect to employment policies. The method recognizes that social policy remains the responsibility of member states, under the principle of subsidiarity. It implies that member states define and evaluate common objectives and learn from each about reaching these objectives. Best practices are disseminated and benchmarking is used. Coordination is based on evaluation and peer pressure, but does not offer the option of sanctions. In Nice it was decided that member states should implement action plans for combating poverty and social exclusion and to define common objectives on social indicators. The indicators encompass financial poverty, income inequality, long-term unemployment, regional variation in employment rates, life expectancy and poor health.

Some consider these common indicators and the national action plans for social inclusion as significant progress towards integration along the social dimension (Atkinson, 2002). Others question this form of coordination (Leibfried, 2002). At least, this new mode of governance and the Lisbon agenda in general, have renewed the debate on poverty reduction in EU member states.

\subsection{Combating poverty}

In September/October 2006, member states adopted renewed National Action Plans for Social Inclusion under the new streamlined open method of coordination as one chapter of the National Report on Strategies for Social Protection and Social Inclusion. They presented the key priorities in member states efforts to promote greater social inclusion and make a decisive impact on the eradication of poverty and social exclusion (European Commission, 2007). A year later, the Commission gave special attention to the poverty among vulnerable groups, especially children, in their Joint Report on Social Protection and Social Inclusion 2008 (European Commission, 2008). In most member states, children are at greater risk of poverty than the overall population. In some countries more than 25 percent of the children are at risk of poverty. Child poverty may have a strong damaging effect on future life opportunities and also on the future capacity of these children to contribute to society (European Commission 2008, p.6). In general, the Report indicates that social inclusion and social protection remains high on the political agenda for most member states. Some member states have reinforced their commitments by setting quantitative targets to reduce poverty (p. 101). The most recent Joint Report 2009 (European Commission 2009, pp. 2-3) states that a boost must be given to Member States' efforts to implement comprehensive strategies against poverty. The current Social Open Method of Coordination Cycle lasts until 2010, the target year for the Lisbon strategy. The Report calls upon strong commitment to achieve the agreed objectives on social protection and social inclusion, and the 2010 European Year for combating poverty and social exclusion reaffirms this.

Progress of social inclusion and poverty reduction is monitored considering the performance in each member state on the basis of national indicators, based on the Social Indictors report of Atkinson et al (2002). In the European Union people are said to be in income poverty if their incomes are below 60 per cent of the median disposable income of households in their country, after adjusting for household size (equivalence scales). ${ }^{2}$ Based on this EU-criterion, the proportion of the EU15-

\footnotetext{
2 The evolution of the European Union will lead increasingly to question poverty-issues in an EU-wide perspective, about both Europe-wide data and the underlying concepts (Atkinson, 2002, p. 626). Up till now EU-wide estimates of poverty play no role. A paper of Brandolini (2006) provides the first estimates of poverty in the enlarged European Union as if it was a single country. European Commission-Eurostat (2008) show estimates applying an EU median income as threshold. In 2005 around 16 percent of total population of Europe had a income below 60 percent of the national median level in the country in which they live, which is the weighted average of the figures for the risk of poverty at national level across the EU (i.e. the indicator used in the OMC in the field of social protection and social inclusion). However, around 22.5 percent of the EU
} 
population who was at risk of poverty in 2007 is 17 percent, with lower statistics for the Nordic countries and higher poverty rates for Mediterranean countries. See Map 1. In EU15 around 54 million citizens are considered as at risk of poverty.

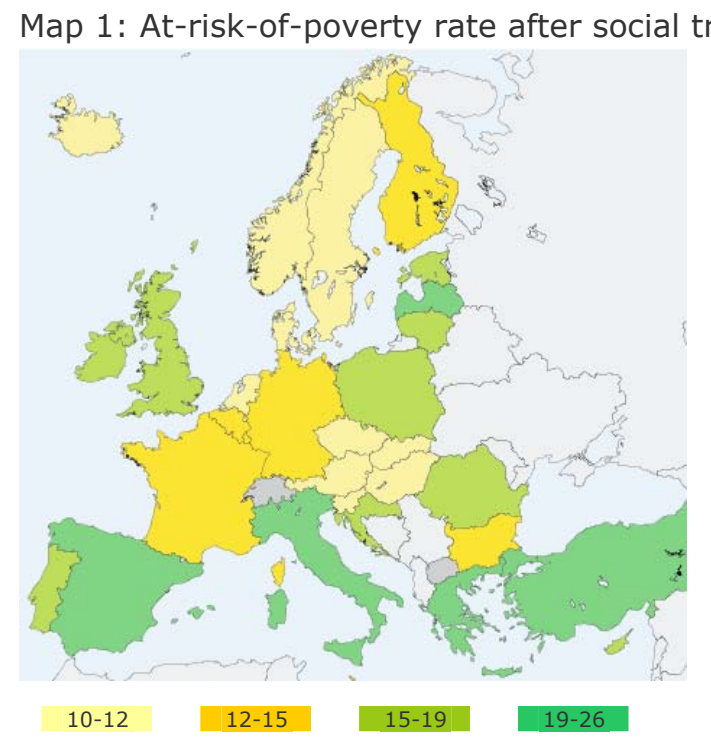

Source: Eurostat: ECHP/EU-SILC (2009)

The poverty problem is also striking in other highly-developed welfare states. Industrialized countries spend a large share of their income on social security, but poverty and social exclusion have not been eradicated. A sizeable proportion of the population lives in economic poverty in all industrial welfare states. According to the most common standards used in international poverty analyses, on average roughly one in ten households live in relative poverty in OECD countries (cf. Atkinson et al. 1995; Behrendt 2002; Smeeding, 2005). The persistence of poverty in industrial welfare states calls for an explanation. If these welfare states offer elaborate systems of income maintenance, why is there still a considerable amount of poverty? Why are some countries more effective than others in this respect? What can explain these variations in effectiveness?

\section{RESEARCH DESIGN}

This paper assesses the relationship between welfare state effort and poverty alleviation. We analyze the reduction of poverty rates through social transfers and taxes and its relationship to welfare state effort. Our research design starts with the data to be used, because poverty rates and social expenditure rates can be collected from several sources. Next, we discuss how to measure social effort and the effect of social transfers on poverty.

\section{1 Measuring poverty incidence}

For various reasons we use poverty rates from different databases. The official EU-indicator for social cohesion is the at-risk-of-poverty rate after social transfers. This rate is defined as the share of persons with an equivalized disposable income below the risk-of-poverty threshold, which is set at 60 percent of the national median equivalized disposable income in each country. For this indicator, Eurostat data (ECHP/EU-SILC) are available for the period 1995-2007, but not for all member states. For a further comparison, we will also use OECD poverty rates. The OECD poverty rate is usually defined as the proportion of individuals with equivalized disposable income less than 50 percent of the median income. In this paper, we will use OECD poverty data from the mid1990's until the year 2005 based onthe OECD study (2008) entitled 'Growing unequal? Income distribution and poverty in OECD countries'. Finally, we use data from the Luxembourg Income 
Study (LIS). The LIS database contains income data files for 32 nations covering the period 1967 to 2005. With this data set we can also analyze both the level and trend in poverty for a considerable period across a wide range of nations.

Following international standards, we use the relative rather than the absolute approach in measuring income poverty. This means that we define those households that have an equivalent disposable income below a certain threshold representing the level of well-being of the population in a specific country as being poor. In our empirical analysis we use several thresholds for a poverty line (40 percent, 50 percent and 60 percent), because the absolute number as well as the structure of poverty differ to a large extent, depending on the threshold chosen. ${ }^{3}$ In most comparative studies the poverty threshold has been set at 50 percent of median equivalent disposable income, but we focus especially on the EU's definition of the poverty line. For comparison, the official United States poverty line was just about 30 percent of median United States disposable post-tax household income in $2007 . .^{4+5}$

It should be noted that there have been controversial arguments regarding the issues in the measurement of poverty. These arguments have their own merits and shortcomings, and there has been little professional consensus among research with regard to the theoretical superiority of a particular way of measuring poverty (Haveman, 2008). Moreover, the availability of reliable data restricts the possibilities for conducting empirical research, which is especially problematic in crossnational studies. The aim of this paper is not to review definitional issues that arise in assessing the extent of, and change in, poverty in western industrialized countries. We simply refer to a vast literature on the sensitivity of measured results to the choice of income definitions, poverty lines, appropriate equivalence scales, and other elements that may affect results in comparative poverty research. $^{6}$

\subsection{Measuring social effort}

The overall result of quantitative studies seems to be that there is strong negative correlation between poverty and social expenditures across European countries over the last 25 years; see among many others Cantillon (2009), Esping-Andersen and Myles (2009), Behrendt (2002), and Kenworthy (1999). We use social expenditure data from the most recent OECD Social Expenditure Database (SOCX 2008). This database contains aggregate and disaggregated data on social expenditures. The main social policy areas included are old age, survivors, family, health and other social programs. Both cash benefits and benefits in kind are included. In this study, we will perform several tests at the aggregate level and at the program level. It should be noted that social expenditure indicators at the aggregate level have their limitations (Kühner, 2007): changes in expenditure ratio's may not be caused by policy changes, but simply by the number of beneficiaries as a result of an ageing population or changes in unemployment levels due to cyclical factors (see also section 3.4).

We distinguish between EU15 and other countries to indicate whether it is Europeanization rather

3 Hagenaars and De Vos (1987) applied eight definitions for a poverty line to a 1983 household survey for the Netherlands: four definitions based on an absolute approach, three on a subjective and one a relative measure. The derived overall poverty rates ranged from 5.7 to 33.5 percent.

4 U.S. Census Bureau's Current Population Survey reports for 2007 a poverty threshold for a 4-persons family (weighted average) of $\$ 21,203$; median disposable income for 4 -persons families amounts $\$ 69,654$.

5 Although US poverty is much higher than poverty in Europe when a relative poverty measure is used, using the official absolute poverty measurement from the US (Orshansky-poverty) alters the picture; see Notten and De Neubourg (2007). Their estimates according to the Orshansky-methodology for 1996 and 2000 show (still) high USA poverty rates, but not that much difference with most European countries, while Greece, Spain and Portugal even have figures four times higher than the USA. It should be noted that this result is highly sensitive for the purchasing power parity rates used to convert the US poverty lines to country specific thresholds of EU15.

6 Among others, see Atkinson (1987 and 2003), Hagenaars and De Vos (1987), Förster (1993), Atkinson et al (1995), Behrendt (2000), Gottschalk and Smeeding (1997 and 2000), Smeeding et al (2000), Marcus and Danziger (2000), Atkinson and Brandolini (2001), Caminada and Goudswaard (2001), Förster and Pearson (2002), Smeeding (2005), Guio (2005), Förster and Mira d'Ercole (2005), OECD (2008) and (other) papers listed in our reference section using data from the Luxembourg Income Study. Recent comprehensive reviews on methodological assumptions underlying international levels and trends in inequality are found in Brandolini and Smeeding (2007 and 2008). See Bourguignon et al (2002) for a more elaborated paper on the evaluation of poverty impact of economic policies. 
than globalization that has had any impact on poverty alleviation (and/or social expenditures). ${ }^{7}$ Other problems with social expenditure as an indicator for differences in social protection across countries are related to differences in the public/private mix in the provision of social protection and differences in features of the tax system. Adema (2001) has developed indicators that aim at measuring the share of an economy's domestic production recipients of social benefits really draw on, net total social expenditure. We prefer to use these net social expenditure ratios rather than gross ratios. Unfortunately, net figures are not available at the level of social programs, so we also have to use gross social expenditure ratios to that end. However, we include private social benefits. For private programs to be considered 'social', they need to have a social purpose and contain an element of interpersonal redistribution and/or compulsory participation. ${ }^{8}$ The distinction between public and private social protection is made on the basis of whoever controls the relevant financial flows. Private social benefits may be important for our analysis. In so far they contain an element of redistribution, they may also have an impact on poverty reduction across countries. For example, private but mandatory pensions (in the second pillar) may have an effect on poverty incidence among the elderly. However, the impact of private social benefits is likely to be smaller than the impact of public social transfers.

The most recent figures of the net social expenditure as percentage of GDP, based on the 2008 edition of the Net Social Expenditure data, indicate that accounting for the impact of taxes and of private social expenditure has an equalizing effect on levels of social effort across countries; see Caminada and Goudswaard (2005) for details.

\subsection{Measuring the anti poverty effects of taxes and social transfers}

Usually, the impact of social policy on income poverty is calculated in line with the work of Musgrave, Case and Leonard (1974), i.e. statutory or budget incidence analysis. Important issues of tax/transfer shifting and behavioral responses are ignored. ${ }^{9} \mathrm{~A}$ standard analysis of the antipoverty effect of taxes and income transfers is to compare pre-tax-transfer poverty and post-taxtransfer poverty (Ringen, 1987; see also OECD 2008, p. 98). To compare the antipoverty effectiveness of taxes and income transfers among western welfare states, poverty rates will be decomposed into the level of market-generated poverty, the overall level of welfare efforts, and the poverty reduction efficiency of taxes and transfers (cf. Kim, 2000a). When calculating poverty rates for both market and disposable income, people are ranked by their disposable incomes, so that the re-ranking effect is eliminated.

A comparison between the standard at-risk-of-poverty rate and the hypothetical situation where social transfers are absent, other things being equal, shows that such transfers have an important redistributive effect that helps to reduce the number of people who are at risk of poverty. ${ }^{10}$ In the absence of all social transfers, the average poverty risk for EU member states would be considerably higher than it is in reality. It should however be noted that the indicator of poverty risk before social transfers must be interpreted with caution (Kim, 2000b; Nell; 2005). First, it is not taken into account that instruments other than social cash transfers can have the effect of raising the disposable incomes of households and individuals, namely transfers in kind, tax credits and tax allowances. Second, the pre-transfer poverty risk is compared to the post-transfer risk keeping all other things equal - namely, assuming unchanged household and labor market structures, thus disregarding any possible behavioral changes that the situation of absence of social transfers would involve. However, behavioral responses - with the strongest effects on reducing work effort - have been at the heart of the policy debates shaping the evolution of

7 It should be mentioned that some non-EU15 countries such as Czech Republic, Iceland, Hungary, Norway, Poland, Slovakia, or Switzerland may also be influenced by European integration, for example via policy competition.

8 Private social programs can be mandatory or voluntary. Mandatory private benefits are often incapacity related. For example, in several countries employers are obliged to provide sickness benefits. Occupational injuries and accidents ('risque professionel') can also be covered by mandatory private insurances. A number of EU member states have supplementary employment-based pension plans with mandatory contributions, based on a funding system. Voluntary private social security covers a wide range of programs, of which private pension plans and private social health insurance constitute major components.

9 See for a critical survey of efforts to measure budget incidence by Smolensky et al (1987).

10 Among others, see Behrendt (2002), Smeeding (2005), Förster and Pearson (2002), Guio (2005) and Förster and Mira d'Ercole (2005). 
antipoverty policy. ${ }^{11} \mathrm{Kim}$ (2000b) showed that both the generosity and efficiency of the tax/transfer system may influence the level of pre-tax-transfer poverty. So, this standard approach overestimates the antipoverty effectiveness of generous and/or targeted welfare systems. Our estimates for effectiveness of poverty reduction of each country should consequently be regarded as upper bounds.

A special feature in our analysis is a technique for treatment of pensions. Public pension plans are generally seen as part of the safety net, generating large antipoverty effects through transfers and taxes (contributions) at one moment in time. A case in point arises when considering contributions to private and occupational pensions and their relation to contributions to public pensions, especially because countries differ to a large extent in public versus private provision of their pensions (OECD, 2008, p. 120). Private occupational pensions are not antipoverty programs per se, although they too have a significant effect on poverty reduction when pre-tax-transfer poverty and post-tax-transfer poverty are measured at one moment in time, particularly among the elderly (Scholtz et al, 2008; Wu, 2005). One could question whether pensions are designed to mitigate the most pernicious aspects of market-based economic outcomes (and thus part of society's safety net). Nevertheless, the standard approach treats contributions to government pensions as a tax that finances the retirement pensions paid out in the same year, while contributions to private pensions are effectively treated as a form of private consumption. This affects international comparisons of antipoverty effects of social transfers and taxes. Overcoming this bias requires a normative approach: should pensions be earmarked as market income or as a transfer? We deal with this bias rather pragmatically by broadening the traditional framework of statutory incidence analysis. We also compute the antipoverty effect of taxes and social transfers other than pension. Recent data of Eurostat allow for such a (new) approach. Comparing at-risk-of-poverty rates with and without pensions identifies the partial effect neglected thus far in this kind of statutory incidence analysis. ${ }^{12}$

\subsection{Tests on the linkages between social protection and poverty reduction}

National preferences for social protection differ substantially across countries. Especially AngloSaxon countries do not seem to be prepared to sustain the high protection levels prevailing in other countries with the same level of income. This may be an expression of cultural differences within the group of OECD countries. These differences could point to variance in the antipoverty nature of social systems as well. Anglo-Saxon welfare states (especially the United States) rely more heavily on private social arrangements as far as pensions, health care and other programs are concerned. However, private social programs may generate a more limited redistribution of resources than public ones, and tax advantages towards private pension and health plans are more likely to benefit the rich. Private employment-related social benefits mostly re-allocate income between the (formerly) employed populations. The same holds for fiscal advantages related to, for example, supplementary private pension plans. In general, we do expect that private schemes will generate less antipoverty effects than public programs.

We perform a cross-national analysis of the relationship between (public and private) social expenditures and poverty rate reduction through transfers ant taxes at one moment in time. The material presented is only descriptive and does not explain poverty alleviation or poverty structure. Such an analysis should ideally be based on a theory, which would have to address at least the following cross-national differences (cf. Gottschalk and Smeeding, 2000, p.263): differences in labor markets that affect earnings of individual household members; demographic differences, such as the ageing of the population and growth of single parent households, which affect both family needs and labor market decisions; and differences across countries in tax and transfers policies that not only affect family income directly, but also may affect work and investment decisions. Two

11 We refer to the seminal review by Danziger, Haveman and Plotnick (1981).

12 An alternative approach to overcome this bias is to re-rank incomes (cf. OECD, 2008, p.109). First, poverty rate of market income is computed by ranking people by their level of market income, and the antipoverty effect of the tax and transfer systems is calculated. In the second step, poverty rate of market income is based on people ranked by their disposable income (i.e. individuals are ranked by where they end up "after" redistribution, rather than where they were placed "before"). The difference between the two measures of redistribution is a result of the re-ranking of some households as a consequence of welfare state programs (for example pensions). 
recent seminal books edited by Kakwani and Silber (2007 and 2008) present the panorama of the many dimensions of poverty from various disciplines. A fully-fledged model should be developed to assess the relative performance of social factors and the economic development. Such a comprehensive approach is far beyond the scope of this paper. ${ }^{13}$ Here we simply employ bi-variate regressions on the relationship between poverty reduction through the transfer and tax system and levels of social expenditures. ${ }^{14}$ However, we will investigate the relationship between poverty alleviation and social expenditures across countries at several moments in time (around 1995, 2000 and 2005) to analyze the influence of the business cycle. Nevertheless one could argue that omitted (macroeconomic) variables cause bias. Differences in social effort across countries at one point in time can be the result of numerous factors.

It should however be mentioned that the European Union have emphasized the multidimensional nature of deprivation, and have developed supplementary indicators of poverty based on social indicators and the broad concept of social exclusion. The European Union has defined common objectives on social indicators to be benchmarked by the streamlined Open Method of Coordination. Both data and measurement techniques have been developed in order to capture a variety of dimensions of deprivation beyond money income (poverty). Another important point to keep in mind is that we only analyze the impact of transfers on poverty, while, as we mentioned before, several other strategies can be chosen to alleviate poverty. In fact, several EU member states are increasingly emphasizing strategies to facilitate labor force participation of lower income groups (European Commission, 2008, p.101). This may also be an effective strategy to tackle poverty.

\section{ANTIPOVERTY EFFECT OF SOCIAL TRANSFERS AND TAXES}

\subsection{Introduction}

In spite of differences in the measurement of poverty and the databases used, most studies have consistently found that there is a large difference in poverty rates among welfare states, depending on the poverty line applied. Reports on poverty profiles for EU15 and other OECD countries for the latest data year available from LIS (2009), OECD (2008) and Eurostat (2009) consistently show in general - Scandinavian and Benelux countries have the lowest poverty rates, followed by continental European countries. Anglo Saxon welfare states have relatively higher poverty rates. Among them, the level of poverty is highest in the United States. ${ }^{15}$ However, country clustering based on poverty rates is quite different from that of welfare state regimes. Among the countries with low poverty rates we find representatives of the social democratic regime and the corporatist regime. Likewise, the nations with higher rates of poverty represent several regime types and both members of the EU15 and the new member states.

In every nation, benefits from governments, net of taxes, reduce relative income poverty. The first columns of Table 1 show relative poverty rates calculated for household market income and for disposable income after transfers and taxes. We compare the different at risk-of-poverty rates before and after social transfers and taxes. In each country, these rates are calculated with the same threshold, namely the nationally-defined 60 percent threshold calculated on the basis of total household income. Remarkably, according to the EU-indicator, poverty increased on average

13 The multidimensional approach of poverty is a complex undertaking (Haveman, 2008, p. 4) and suffers from several difficulties, among which the most serious is the estimation of the interaction between attributes (dimensions of poverty). One has to define a list of attributes to be taken into account and decide how much weight to give to each of these dimensions. Thorbecke (2007, p. 17-18) concludes: "It should be clear that a complete mapping of combination of attributes into the utility space appears daunting, if not altogether utopian." "..., there are too many unresolved questions left over to consider seriously using multidimensional measures in any truly operational sense."

14 We refer to related work. Caminada and Goudwaard (2010) perform a multiple analysis on poverty and social expenditures in a cross country perspective. We take into account the most commonsense (control) variables to be examined: the ratio of the elderly population (for old age pensions), the unemployment rate of total labor force (for the business cycle), and GDP per capita US dollars (current prices and PPS).

15 See Caminada and Goudswaard (2010) for a review. Data on poverty rates and poverty alleviation among 28 OECD countries, and correlation tests (relationship with social income transfers) are posted at and available from Caminada's webpage. 
between 2000 and 2007, especially in Belgium, Finland, Germany, Italy, Luxembourg and Spain. ${ }^{16}$ When analyzing the hypothetical case of the complete absence of social transfers (other than pensions), in EU15 countries an average of 26 percent of the population would be at-risk-ofpoverty. Note that in the EU data retirement and survivor's pensions are usually counted as income before transfers and not as social transfers, because the prime role of old age (and survivors') pensions is not to re-distribute income across individuals but rather over the life-cycle of individuals. Alternatively, pensions could be excluded from at risk of poverty rates "before social transfers and taxes"; those figures are presented between brackets in Table 1.

Table 1: EU at-risk-of-poverty rate before and after social transfers and taxes, 1995-2007

\begin{tabular}{|c|c|c|c|c|c|c|c|c|c|}
\hline \multirow[b]{3}{*}{ Austria } & \multicolumn{6}{|c|}{$\begin{array}{l}\text { Poverty rates before social transfers and } \\
\text { taxes }\end{array}$} & \multicolumn{3}{|c|}{$\begin{array}{c}\text { Poverty rates after transfers and } \\
\text { taxes }\end{array}$} \\
\hline & \multicolumn{2}{|c|}{1995} & \multicolumn{2}{|c|}{2000} & \multicolumn{2}{|c|}{2007} & 1995 & 2000 & 2007 \\
\hline & & (41) & & (37) & 25 & (43) & 13 & 12 & 12 \\
\hline Belgium & 27 & $(42)$ & 23 & (40) & 28 & (42) & 16 & 13 & 15 \\
\hline Denmark & & & & & 27 & (37) & 10 & & 12 \\
\hline Finland & & & 19 & (32) & 29 & (41) & & 11 & 13 \\
\hline France & 26 & $(42)$ & 24 & (41) & 26 & (46) & 15 & 16 & 13 \\
\hline Germany & 22 & (38) & 20 & (39) & 25 & (43) & 15 & 10 & 15 \\
\hline Greece & 23 & (38) & 22 & (39) & 24 & (42) & 22 & 20 & 20 \\
\hline Ireland & 34 & (42) & 31 & (37) & 33 & (40) & 19 & 20 & 18 \\
\hline Italy & 23 & (40) & 21 & (42) & 24 & (43) & 20 & 18 & 20 \\
\hline Luxembourg & 25 & (40) & 23 & (39) & 23 & (39) & 12 & 12 & 14 \\
\hline Netherlands & 24 & (38) & 22 & (35) & 21 & (35) & 11 & 11 & 10 \\
\hline Portugal & 27 & (37) & 27 & (38) & 24 & (40) & 23 & 21 & 18 \\
\hline Spain & 27 & (41) & 22 & (37) & 24 & (39) & 19 & 18 & 20 \\
\hline Sweden & & & & & 28 & (42) & & & 11 \\
\hline United Kingdom & 32 & (41) & 29 & (41) & 30 & (42) & 20 & 19 & 19 \\
\hline EU15 & 26 & $(40)$ & 23 & $(40)$ & 26 & $(42)$ & 17 & 15 & 17 \\
\hline
\end{tabular}

Note: Poverty threshold is set at 60 percent of the national median equivalized disposable income (after social transfers). Figures between brackets represent poverty rates where pensions are excluded from income before transfers and taxes. In all cases, the risk-of-poverty threshold (before and after social transfers and taxes) is set at 60 percent of the national median equivalized disposable income.

Source: Eurostat: ECHP/EU-SILC (2009) and own calculations

We calculate an absolute measure of poverty reduction - the absolute antipoverty effect is the percentage point difference between the poverty rate before and after taxes and transfers. A comparison of the number of people on low incomes before social benefits other than pensions and those on low incomes after social benefits illustrates one of the main purposes of such benefits: their redistributive effect and, in particular, their ability to alleviate the risk of poverty and reduce the percentage of population (having to manage) with a low income. In 2007, the average at-riskof-poverty rate in EU15 countries was 26 percent before social transfers other than pensions and 17 percent when calculated after all social transfers and taxes. So, social transfers were successful in lifting 35 percent of persons with low income above the poverty line. Social benefits other than pensions reduce the percentage of people at risk of poverty in all the countries, but to very disparate degrees. The reduction is smallest (less than 25 percent) in some Mediterranean States (Greece, Spain, Italy, and Portugal). The reduction is greatest in Sweden (61 percent); Denmark, Finland, the Netherlands, Austria and France also record reductions due to social transfers of 50

16 This result should be interpreted with caution, because there is a disruption in the time series of poverty indicators presented in Table 1. Until 2001, data were provided by the European Community Household Panel survey (ECHP). Since 2005 all EU-15 countries provide data from the new European Union Statistics on Income and Living Conditions (EU-SILC). During the transitional period poverty indicators were provided by national sources which were harmonized ex-post as closely as possible with EU-SILC definitions by Eurostat. Despite the fact that most EU-SILC variables are defined in the same way as the corresponding ECHP variables, some differences arise. See for more details 'The continuity of indicators during the transition between ECHP and EU-SILC' from Eurostat (2005). 
percent or more. In the absence of social benefits other than pensions, in 2007 in two member states (Ireland and the United Kingdom) 30 percent or more of the population would have been atrisk-of-poverty.

Figure 1 illustrates these pronounced differences in the performance of the social protection systems of the EU15 countries in reducing poverty for 2007 . The antipoverty effect of social transfers (other than pensions) and taxes amounts 9 percentage points for EU15. Figure 1 points at some 'best-practices' for the EU15 countries in combating poverty. Countries are listed is descending order of the magnitude of their poverty rates after social transfers and taxes. The Netherlands have the lowest poverty rate in the EU15 (10 percent); Greece, Italy and Spain have the highest poverty score (20 percent of entire population). In panel (a) retirement and survivor's pensions are counted as income before transfers; in panel (b) pensions are excluded from. In the latter case the antipoverty effect of social transfers (and taxes) is much higher. However, Spain still produces a relatively low antipoverty effect. In this case the best-practices for 2007 is found in France.

Figure 1: Antipoverty effect of social transfers and taxes, EU15, total population, 2007

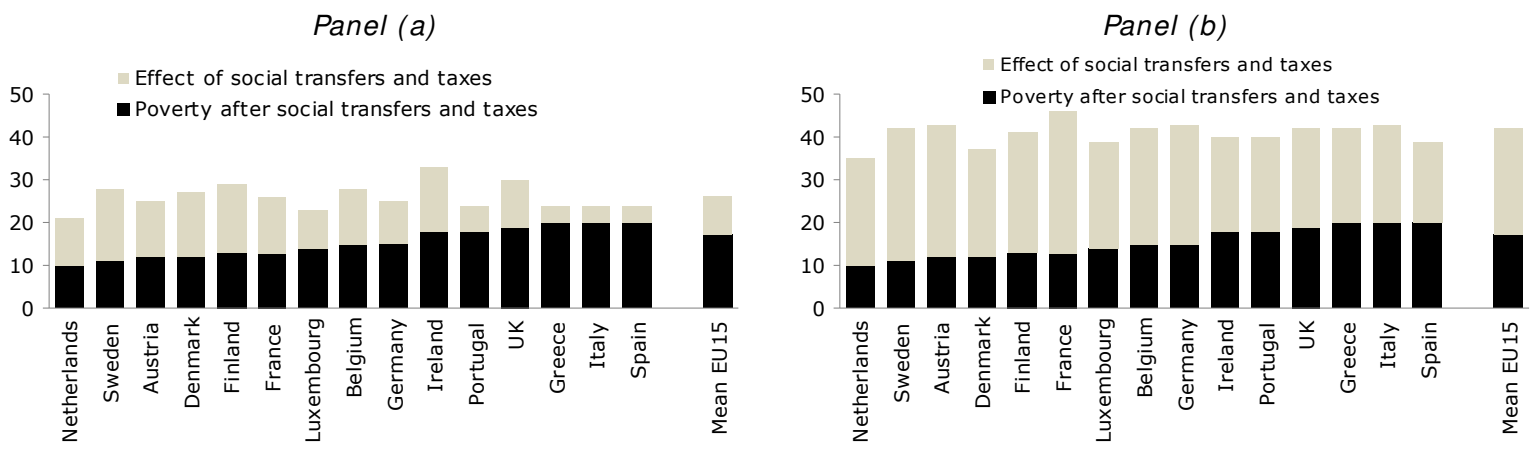

Panel (a) Pensions are included in social transfers in at risk of poverty rates before social transfers Panel (b) Pensions are excluded from social transfers in at risk of poverty rates before social transfers

Source: Eurostat: ECHP/EU-SILC (2009); own calculations

Next, we also include eleven non-EU15 countries as a benchmark into our analysis. We calculated the antipoverty effect of social transfers and taxes based on up-dated figures from the OECD (2008, p. 141) for 25 countries. This dataset measures the difference between poverty rates based on disposable incomes and those based on market income. A 50 percent threshold is applied for the poverty line instead of the 60 percent of the official EU-indicator. ${ }^{17}$ In general antipoverty effects of social transfers and taxes are somewhat higher for most EU15 countries compared to outcomes of the official EU-statistics used in the previous analysis (Figure 1), although results are hardly comparable. ${ }^{18}$

In all OECD countries, public cash benefits and taxes significantly reduce poverty. Table 2 highlights differences across countries in the role of government taxes and cash benefits in reducing poverty. As reported by OECD (2008, p. 291-292), most of the redistribution towards people at the bottom of the income scale is generally achieved through public cash benefits - with the main exception of the Unites States, where a large part of the support provided to low-income families is administered through the income tax system (EITC). These cross-country differences in the scale of redistribution partly reflect differences in the size and structure of social spending. OECD countries redistribute in a variety of ways - some through universal benefits, others with more targeted programs, some mainly relying on transfers, others mainly granting tax rebates to low-income families.

17 For this analysis we prefer using OECD-data rather than LIS-data. LIS also presents poverty rates for market income and for disposable income (based on the work of Mahler and Jesuit (2006)); however, the LIS Fiscal Redistribution Dataset covers only 13 countries between 1979-2002.

18 Among other factors, depending on the density of low income population between 50 and 60 percent of median income in the countries, which varies by country. 
Table 2: OECD poverty scores of market income and disposable income, around 2005

\begin{tabular}{|c|c|c|c|}
\hline & $\begin{array}{l}\text { Poverty rate } \\
\text { market income } \\
\text { (PL50) }\end{array}$ & $\begin{array}{c}\text { Poverty rate } \\
\text { disposable income } \\
\text { (PL50) }\end{array}$ & $\begin{array}{l}\text { Effect of social } \\
\text { transfers and taxes }\end{array}$ \\
\hline \multicolumn{4}{|l|}{ EU15 } \\
\hline Austria & 23 & 7 & 16 \\
\hline Belgium & 33 & 9 & 24 \\
\hline Denmark & 24 & 5 & 18 \\
\hline Finland & 18 & 7 & 10 \\
\hline France & 31 & 7 & 24 \\
\hline Germany & 34 & 11 & 23 \\
\hline Ireland & 31 & 15 & 16 \\
\hline Italy & 34 & 11 & 22 \\
\hline Luxembourg & 29 & 8 & 21 \\
\hline Netherlands & 25 & 8 & 17 \\
\hline Portugal & 29 & 13 & 16 \\
\hline Sweden & 27 & 5 & 21 \\
\hline United Kingdom & 26 & 8 & 18 \\
\hline \multicolumn{4}{|l|}{ Non-EU15 } \\
\hline Australia & 29 & 12 & 16 \\
\hline Canada & 23 & 12 & 11 \\
\hline Czech Republic & 28 & 6 & 22 \\
\hline Iceland & 20 & 7 & 13 \\
\hline Japan & 27 & 15 & 12 \\
\hline Korea & 18 & 15 & 3 \\
\hline New Zealand & 27 & 11 & 16 \\
\hline Norway & 24 & 7 & 17 \\
\hline Poland & 38 & 15 & 23 \\
\hline Slovakia & 27 & 8 & 19 \\
\hline United States & 26 & 17 & 9 \\
\hline Mean OECD-25 & 27.0 & 10.0 & 17.0 \\
\hline Mean EU15 & 27.8 & 8.8 & 19.0 \\
\hline Mean non-EU15 & 26.0 & 11.3 & 14.7 \\
\hline
\end{tabular}

Source: OECD (2009, p. 139-141), and own calculations

EU15 countries show an antipoverty effect of 19.0 percentage points on average, while non-EU15countries produce on average a lower antipoverty effect of 14.7 percentage points among their population. Best-practices at the top of this list are found for Belgium, France, Poland, Germany, Italy and the Czech Republic. On the bottom of this country ranking we find Korea and the United States with antipoverty effects of less than 10 percentage points. Remarkably, the United States relative poverty rate before taxes and social transfers is actually below average for the selected countries (and below EU15-average), even though the United States ranks the highest of all the countries in this comparison group in relative poverty rates after taxes and transfers. Given this divergence, it should be no surprise that of the countries listed, the United States (and Japan) devotes the smallest share of its resources to public antipoverty income transfer programs (cf. Smeeding, 2005). ${ }^{19}$ However, when private social expenditures are also taken into account, this picture alters. In that case, the United States rank fifth when all 25 countries are ordered on basis of their level of total social expenditures. So, public versus private social expenditures may have opposite antipoverty effects (cf. Caminada and Goudswaard, 2010). Moreover, these large crosscountry differences in the antipoverty effect of social transfers and taxes call upon for further explanation.

19 Scholz et al (2008, p. 30) question why U.S. anti-poverty spending has been low and relatively stable last decades given its persistent and high poverty rates by international standards. 


\subsection{The impact of welfare state effort in the EU15 around 2005-2007}

Next we turn to the reduction of poverty rates through social transfers and taxes and its relationship to welfare state effort. Table 3 presents the linkage between poverty reduction and social expenditure ratios for EU15 countries. This gives a picture of the targeting of social protection efforts across EU15 countries at one moment in time (around 2005-2007). Absolute antipoverty effects are divided by net social spending ratios to see which country targets best per one point of GDP spent on social expenditure. This way we provide for an indicator on Public Policy Effectiveness on Poverty Alleviation across countries.

Our analysis highlights some cross-country differences of poverty alleviation in the EU15, although the ranking must be interpreted with caution due to cyclical factors. When we rank countries according to their 'effectiveness' of combating poverty (column 7), each percentage point of net social expenditure alleviates poverty in Ireland and the Scandinavian countries by .7-.9 percentage points, while the lowest scores are found in Italy and Spain (.2). Relative to their level of net social expenditure, Sweden (24.8 percent of GDP) was expected to have a good performance in alleviating poverty. In contrast, France and Germany realize less reduction in poverty rates, but on a markedly higher level of net social expenditure (respectively 29 and 27 percent of GDP).

This result of country ranking is open to debate, mainly because pensions could also be counted as social transfers. In that case our country ranking alters somewhat: best-practices are found in Finland and Ireland, while the United Kingdom is found at the bottom of the list. See Table 3.

Table 3: Targeting effect of net social expenditure on poverty reduction EU15, around 2005-2007

\begin{tabular}{|c|c|c|c|c|c|c|c|c|}
\hline & \multicolumn{3}{|c|}{$\begin{array}{l}\text { Poverty rate total population } \\
\text { (PL 60) before and after social } \\
\text { transfers and taxes, } 2007\end{array}$} & \multicolumn{2}{|c|}{$\begin{array}{c}\text { Effect of social } \\
\text { transfers and taxes }\end{array}$} & \multirow{2}{*}{$\begin{array}{c}\text { Net total } \\
\text { social } \\
\text { expenditure, } \\
\% \text { GDP, } 2005\end{array}$} & \multicolumn{2}{|c|}{ Targeting effect } \\
\hline & $\begin{array}{l}\text { Before } \\
\text { pensions } \\
\text { excluded }{ }^{\text {a }} \\
(1)\end{array}$ & $\begin{array}{c}\text { Before } \\
\text { pensions } \\
\text { included } \\
\text { b } \\
(2)\end{array}$ & $\begin{array}{l}\text { After } \\
\text { (3) } \\
\end{array}$ & $\begin{array}{l}(1)-(3) \\
(4)\end{array}$ & $\begin{array}{l}(2)-(3) \\
(5) \\
\end{array}$ & & $\begin{array}{c}(4):(6) \\
(7)\end{array}$ & $\begin{array}{l}(5):(6) \\
(8)\end{array}$ \\
\hline Austria & 25 & 43 & 12 & 13 & 31 & 23.5 & 0.55 & 1.32 \\
\hline Belgium & 28 & 42 & 15 & 13 & 27 & 26.8 & 0.49 & 1.01 \\
\hline Denmark & 27 & 37 & 12 & 15 & 25 & 21.6 & 0.70 & 1.16 \\
\hline Finland & 29 & 41 & 13 & 16 & 28 & 19.5 & 0.82 & 1.43 \\
\hline France & 26 & 46 & 13 & 13 & 33 & 29.0 & 0.45 & 1.14 \\
\hline Germany & 25 & 43 & 15 & 10 & 28 & 27.0 & 0.37 & 1.04 \\
\hline Greece & 24 & 42 & 20 & 4 & 22 & n.a. & n.a. & n.a. \\
\hline Ireland & 33 & 40 & 18 & 15 & 22 & 16.1 & 0.93 & 1.37 \\
\hline Italy & 24 & 43 & 20 & 4 & 23 & 23.1 & 0.17 & 1.00 \\
\hline Luxembourg & 23 & 39 & 14 & 9 & 25 & 20.3 & 0.44 & 1.23 \\
\hline Netherlands & 21 & 35 & 10 & 11 & 25 & 23.3 & 0.47 & 1.08 \\
\hline Portugal & 24 & 40 & 18 & 6 & 22 & 21.4 & 0.28 & 1.03 \\
\hline Spain & 24 & 39 & 20 & 4 & 19 & 19.1 & 0.21 & 1.00 \\
\hline Sweden & 28 & 42 & 11 & 17 & 31 & 24.8 & 0.68 & 1.25 \\
\hline United Kingdom & 30 & 42 & 19 & 11 & 23 & 25.9 & 0.42 & 0.89 \\
\hline Mean EU15 & 26 & 42 & 17 & 9 & 25 & 23.0 & 0.39 & 1.09 \\
\hline
\end{tabular}

- (a) Pensions are excluded from social transfers in at risk of poverty rates before social transfers

- (b) Pensions are included in social transfers in at risk of poverty rates before social transfers

Source: Eurostat: ECHP/EU-SILC (2009), SOCX (2008), and own calculations

Within the group of EU15 countries, we do not find a significant relationship between (high) levels of net social expenditure in 2005 and (high) antipoverty effects of social transfers and taxes in 2007; see Figure 2 (panel a). Evidently, social spending is not the only determinant of a country's poverty outcome. However, when pensions are treated as transfers - instead of as primary income - the antipoverty effect of social transfers and taxes is enormous. As a result the relationship between (high) levels of net social expenditure and (high) antipoverty effects of social transfers and taxes becomes significant $\left(R^{2}=.38 ; \rho<.01\right)$; see Figure 2 (panel b) and the Appendix for details. In this case social spending seems to be an important determinant of a country's poverty outcome, especially among the elderly; see section 5.2 . 
Figure 2: Linkage between net social expenditure and relative poverty rate reduction among EU15countries, around 2005-2007
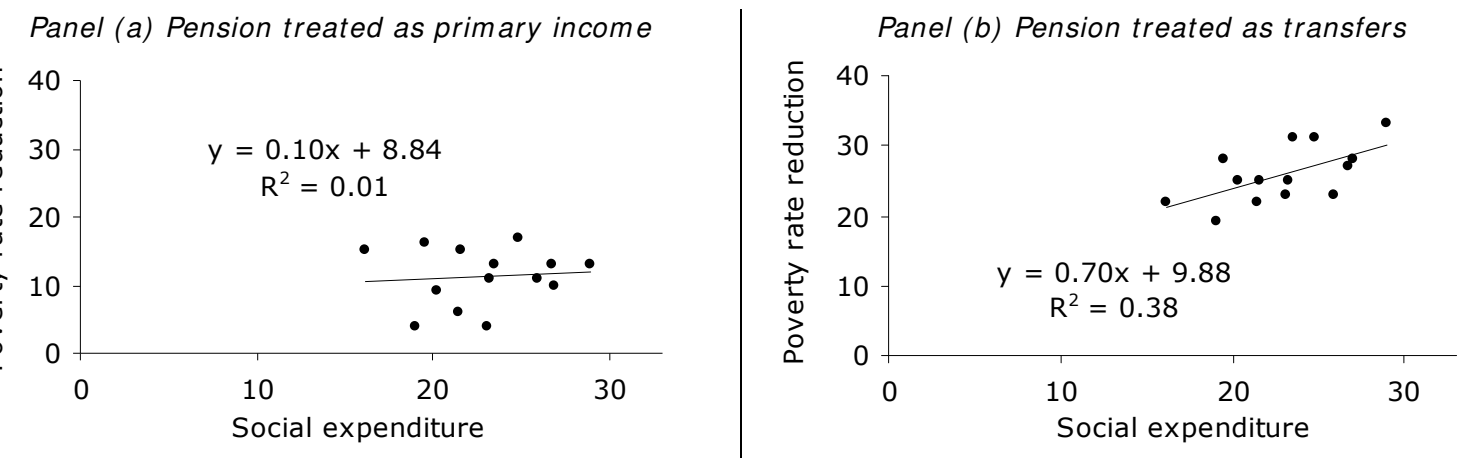

Source: Eurostat: ECHP/EU-SILC (2009), SOCX (2008), and own calculations

\subsection{The impact of welfare state effort in EU15 over time}

Especially the high figures of 'effectiveness' of combating poverty for Ireland in 2007 seem to be influenced by the recent economic performance in this particular country (high economic growth, low unemployment rates, and (therefore) the lowest level of social expenditures). For this reason we employed a sensitivity analysis for the year 1995. Due to lack of data on net social spending over time, we use gross social spending as expenditure variable, however, we take private arrangement into account. Again absolute antipoverty effects are divided by social spending ratios to see which country targets best per one point of GDP spent on social expenditure around 1995 and around 2005-2007. See Table 4.

Table 4: Targeting effect of gross total social expenditure on poverty reduction in the EU15, around 1995 and around 2005-2007

\begin{tabular}{|c|c|c|c|c|c|c|}
\hline & \multicolumn{2}{|c|}{ Around 1995} & \multicolumn{2}{|c|}{ Around 2005-2007 } & \multicolumn{2}{|c|}{ Change over time } \\
\hline & $\begin{array}{l}\text { Pensions } \\
\text { excluded }^{\mathrm{a}}\end{array}$ & $\begin{array}{l}\text { Pensions } \\
\text { included }\end{array}$ & $\begin{array}{l}\text { Pensions } \\
\text { excluded }{ }^{\mathrm{a}}\end{array}$ & $\begin{array}{l}\text { Pensions } \\
\text { included }{ }^{\mathrm{b}}\end{array}$ & $\begin{array}{l}\text { Pensions } \\
\text { excluded }{ }^{a}\end{array}$ & $\begin{array}{l}\text { Pensions } \\
\text { included }\end{array}$ \\
\hline Austria & 0.38 & 0.98 & 0.45 & 1.07 & 0.07 & 0.09 \\
\hline Belgium & 0.39 & 0.92 & 0.42 & 0.87 & 0.03 & -0.05 \\
\hline Denmark & n.a. & n.a. & 0.51 & 0.85 & n.a. & n.a. \\
\hline Finland & n.a. & n.a. & 0.59 & 1.03 & n.a. & n.a. \\
\hline France & 0.36 & 0.88 & 0.40 & 1.03 & 0.04 & 0.15 \\
\hline Germany & 0.24 & 0.78 & 0.34 & 0.94 & 0.10 & 0.16 \\
\hline Greece & 0.05 & 0.83 & 0.18 & 0.99 & 0.13 & 0.16 \\
\hline Ireland & 0.86 & 1.32 & 0.83 & 1.22 & -0.03 & -0.10 \\
\hline Italy & 0.13 & 0.83 & 0.15 & 0.85 & 0.02 & 0.02 \\
\hline Luxembourg & 0.63 & 1.35 & 0.37 & 1.03 & -0.26 & -0.32 \\
\hline Netherlands & 0.42 & 0.88 & 0.38 & 0.86 & -0.04 & -0.02 \\
\hline Portugal & 0.22 & 0.77 & 0.26 & 0.94 & 0.04 & 0.17 \\
\hline Spain & 0.37 & 1.01 & 0.18 & 0.88 & -0.19 & -0.13 \\
\hline Sweden & n.a. & n.a. & 0.53 & 0.96 & n.a. & n.a. \\
\hline United Kingdom & 0.45 & 0.78 & 0.39 & 0.81 & -0.06 & 0.03 \\
\hline Mean EU12 & 0.36 & 0.94 & 0.35 & 0.96 & -0.01 & 0.02 \\
\hline
\end{tabular}

- (a) Pensions are excluded from social transfers in at risk of poverty rates before social transfers

- (b) Pensions are included in social transfers in at risk of poverty rates before social transfers

- EU12: excluding Denmark, Finland and Sweden

Source: Eurostat: ECHP/EU-SILC (2009), SOCX (2008), and own calculations

On average, the targeting effect of social spending did not change much during the period 19952007. Our indicator of Public Policy Effectiveness on Poverty Alleviation improved in seven countries and declined in five EU15 countries. Especially Luxembourg and Spain show notable lower figures for around 2005-2007, while Greece improved their performance relatively well. When pensions are considered as primary income, Ireland ranks on top, both in 1995 and around 2005- 
2007. Also the bottom of our country ranking seems rather stable over time (Italy and Greece). So, as far as the targeting effect of welfare state effort within EU15 concerned, both top and bottom positions of our ranking are rather steady over the business cycle. Note, however, that country ranking depends on how pensions are treated. Moreover, Denmark, Finland and Sweden were not taken into account due to lack of time-series data for these countries.

\subsection{Benchmarking with non-EU15 countries}

As a benchmark we also include eleven non-EU15 countries in our analysis. Our picture of the targeting of social transfers and taxes on poverty reduction is based upon OECD data (2008, p. 141) applying a 50 percent threshold for poverty. We distinguish between EU15 and non-EU15 countries, and rank countries according to their 'effectiveness' of combating poverty. However, cross-national comparison of total social spending is rather sensitive with respect to expenditures related to health care programs, especially when EU15 countries and non-EU15 countries are compared. For example, among all countries the United States spent most on health programs (49 percent of public and private social expenditure), while figures for EU15 are much lower (27 percent on average). One could argue either way: health expenditures generally do not qualify as income transfers; at the same time health programs are an important element of the safety net in most countries, probably generating large antipoverty effects through benefits in kinds and taxes (contributions). We undertake a pragmatic approach, because including or neglecting health expenditure will affect our indicator of Public Policy Effectiveness on Poverty Alleviation across countries to a large extent. We employ both total social spending and total social spending excluding expenditures for health programs. The latter figures are presented within brackets in Table 5. ${ }^{20}$ To capture health expenditures, we have to use gross rather than net social expenditures for this analysis; both public and private social arrangement are taken into account.

Remarkably, each percentage point of total social expenditure alleviates poverty in both EU15 and non-EU15 countries on average by .7 percentage points. For EU15 countries we (again) find a topposition for Ireland, while surprisingly Finland scores lowest in this ranking. Outside EU15, each percentage point of total social expenditure alleviates poverty with 1.1-1.3 percentage points in the Czech Republic, Slovakia and Poland, while the lowest scores are found in Korea and the United States (.3-.4). Especially the targeting effectiveness of the United States is remarkably low, and lies just below half of the average of all countries presented in Table 5. Two factors seem to be of importance. First, excluding health expenditures improves the targeting effect of (remaining) social spending on poverty reduction of the United States considerably. Obviously, excluding health expenditure generates higher targeting results for other countries as well (although to a lesser extent), leaving the cross-national ranking of the targeting scores more or less unaltered. The lowest scores are still found for Korea and the United States. Secondly, a threshold of 50 percent of median income is applied, while US social policy target on lower levels of income to lift people out of poverty.

20 Following SOCX (2008) "health" comprises all public expenditure on health is included (not total health expenditure): current expenditure on health, personal and collective services and investment. Expenditure in this category encompasses, among other things, expenditure on in-patient care, ambulatory medical services and pharmaceutical goods. (Individual health expenditure, insofar as it is not reimbursed by a public institution, is not included; cash benefits related to sickness are recorded under sickness benefits). Voluntary private social health expenditure are estimates on the benefits to recipients that derive from private health plans which contain an element of redistribution, such private health insurance plan are often employment-based and/or tax-advantaged. 
Table 5: Targeting effect of gross total social expenditure on poverty reduction in 25 countries, 2005

\begin{tabular}{|c|c|c|c|c|c|c|c|}
\hline \multirow[b]{3}{*}{ EU15 } & \multicolumn{2}{|c|}{$\begin{array}{c}\text { Poverty rates (PL 50) } \\
\text { total population } \\
\text { before and after } \\
\text { social transfers and } \\
\text { taxes }\end{array}$} & \multirow[t]{2}{*}{$\begin{array}{l}\text { Effect social } \\
\text { transfers and } \\
\text { taxes }\end{array}$} & \multirow{2}{*}{\multicolumn{2}{|c|}{$\begin{array}{c}\text { Gross public and } \\
\text { private social } \\
\text { expenditure, \% GDP }\end{array}$}} & \multirow{2}{*}{\multicolumn{2}{|c|}{ Targeting effect }} \\
\hline & Before & After & & & & & \\
\hline & & & & & & & \\
\hline Ireland & 31 & 15 & 16 & 18.0 & $(10.9)$ & 0.89 & $(1.48)$ \\
\hline Luxembourg & 29 & 8 & 21 & 24.3 & $(17.1)$ & 0.86 & $(1.23)$ \\
\hline Italy & 34 & 11 & 22 & 27.1 & $(20.2)$ & 0.83 & (1.11) \\
\hline Belgium & 33 & 9 & 24 & 30.9 & $(23.1)$ & 0.77 & (1.04) \\
\hline Germany & 34 & 11 & 23 & 29.7 & $(21.0)$ & 0.76 & $(1.07)$ \\
\hline France & 31 & 7 & 24 & 32.2 & $(23.0)$ & 0.73 & $(1.02)$ \\
\hline Sweden & 27 & 5 & 21 & 32.2 & $(25.4)$ & 0.66 & $(0.84)$ \\
\hline Portugal & 29 & 13 & 16 & 25.0 & $(17.4)$ & 0.65 & $(0.93)$ \\
\hline United Kingdom & 26 & 8 & 18 & 28.4 & $(20.4)$ & 0.63 & $(0.88)$ \\
\hline Denmark & 24 & 5 & 18 & 29.5 & $(23.5)$ & 0.62 & $(0.78)$ \\
\hline Netherlands & 25 & 8 & 17 & 29.2 & $(21.4)$ & 0.58 & $(0.80)$ \\
\hline Austria & 23 & 7 & 16 & 29.1 & $(21.8)$ & 0.57 & $(0.75)$ \\
\hline Finland & 18 & 7 & 10 & 27.2 & $(20.8)$ & 0.38 & $(0.49)$ \\
\hline \multicolumn{8}{|l|}{ Non-EU15 } \\
\hline Czech Republic & 28 & 6 & 22 & 19.8 & $(13.5)$ & 1.13 & $(1.65)$ \\
\hline Slovak Republic & 27 & 8 & 19 & 17.6 & $(12.3)$ & 1.09 & $(1.56)$ \\
\hline Poland & 38 & 15 & 23 & 21.0 & $(16.7)$ & 1.09 & (1.37) \\
\hline New Zealand & 27 & 11 & 16 & 18.9 & $(11.6)$ & 0.84 & $(1.36)$ \\
\hline Australia & 29 & 12 & 16 & 20.8 & $(14.3)$ & 0.78 & (1.14) \\
\hline Norway & 24 & 7 & 17 & 23.7 & $(17.9)$ & 0.73 & $(0.96)$ \\
\hline Iceland & 20 & 7 & 13 & 21.8 & $(15.5)$ & 0.59 & $(0.83)$ \\
\hline Japan & 27 & 15 & 12 & 22.4 & $(15.9)$ & 0.53 & $(0.75)$ \\
\hline Canada & 23 & 12 & 11 & 22.0 & $(14.0)$ & 0.50 & $(0.79)$ \\
\hline United States & 26 & 17 & 9 & 26.0 & $(13.2)$ & 0.35 & $(0.69)$ \\
\hline Korea & 18 & 15 & 3 & 9.3 & $(5.9)$ & 0.31 & $(0.49)$ \\
\hline Mean OECD-25 & 26.6 & 9.9 & 16.7 & 24.4 & $(17.4)$ & 0.70 & $(0.98)$ \\
\hline Mean EU15 & 27.8 & 8.8 & 19.0 & 27.9 & $(20.5)$ & 0.68 & $(0.93)$ \\
\hline Mean non-EU15 & 25.3 & 11.1 & 14.3 & 20.3 & $(13.7)$ & 0.72 & (1.07) \\
\hline
\end{tabular}

Note: Figure between brackets exclude social expenditure for health programs.

Source: OECD (2008, p. 141), SOCX (2008), and own calculations

Within the group of EU15 countries we do not find a significant relationship between (high) levels of gross public and private social expenditure and (high) antipoverty effects of social transfers and taxes across countries $\left(R^{2}=.28 ; \rho>.06\right)$, in line with our analysis of section 4.2 . Also for non-EU15 countries such a relationship cannot be found. Moreover, we did several correlation tests with slightly other specifications for the social expenditure variable (including and excluding health programs; gross or net of taxes), but it is hard to find a significant relationship between levels of social spending and antipoverty effects of social transfers and taxes in 2005 . The Appendix presents details.

One could argue that the results presented so far could also be sensitive to the data year chosen (around 2005). Therefore, we performed a sensitivity analysis for those countries where data around 1995 and 2005 are available. Table 6 show the targeting effect of one percentage point of GDP spent on social expenditure around 1995 and around 2005 in a comparative setting. Country rankings based on our indicator for Public Policy Effectiveness on Poverty Alleviation for 1995 and for 2005 are presented between brackets.

Note that the effect of social transfers and taxes in reducing poverty did not change (that much) on average across countries last decade. Targeting declined modestly in EU15 countries (in line with 
Table 4), and increased somewhat in non-EU15 countries. Relatively large drops are found for Belgium, New Zealand and Finland, while Japan, Italy and Germany increased effectiveness since 1995. The ranking of countries according to their targeting effect appears to be rather stable over time. Nevertheless Italy, Germany, Japan and Portugal rank notable higher in 2005 (upwards 3 positions), while Portugal, Sweden and the United Kingdom are positioned 3 or 4 ranks lower in our table of effectiveness in combating poverty with transfers/tax systems.

Table 6: Targeting effect of gross total social expenditure on poverty reduction, around 1995 and 2005

\begin{tabular}{l|cc|cc|cccr|r|}
\cline { 2 - 10 } & \multicolumn{2}{|c|}{$\begin{array}{c}\text { Poverty reduction } \\
\text { social transfers } \\
\text { and taxes }\end{array}$} & \multicolumn{2}{|c|}{$\begin{array}{c}\text { Gross public and } \\
\text { private social } \\
\text { expenditure }\end{array}$} & \multicolumn{4}{|c}{ Targeting effect } \\
& 1995 & 2005 & 1995 & 2005 & 1995 (rank) & 2005 (rank) & Change \\
\hline Australia & 17 & 16 & 21.1 & 20.8 & 0.80 & $(4)$ & 0.78 & $(4)$ & -0.02 \\
Belgium & 26 & 24 & 28.4 & 30.9 & 0.91 & $(3)$ & 0.77 & $(5)$ & -0.14 \\
Canada & 14 & 11 & 23.3 & 22.0 & 0.59 & $(12)$ & 0.50 & $(14)$ & -0.09 \\
Czech Republic & 21 & 22 & 18.3 & 19.8 & 1.14 & $(1)$ & 1.13 & $(1)$ & -0.01 \\
Denmark & 20 & 18 & 31.3 & 29.5 & 0.65 & $(10)$ & 0.62 & $(11)$ & -0.03 \\
Finland & 16 & 10 & 32.2 & 27.2 & 0.49 & $(14)$ & 0.38 & $(15)$ & -0.11 \\
Germany & 20 & 23 & 29.6 & 29.8 & 0.68 & $(9)$ & 0.76 & $(6)$ & 0.07 \\
Italy & 17 & 22 & 24.0 & 27.1 & 0.70 & $(8)$ & 0.83 & $(3)$ & 0.13 \\
Japan & 5 & 12 & 14.8 & 22.4 & 0.36 & $(16)$ & 0.53 & $(13)$ & 0.18 \\
Netherlands & 18 & 17 & 30.6 & 29.2 & 0.58 & $(13)$ & 0.58 & $(12)$ & 0.00 \\
New Zealand & 19 & 16 & 19.4 & 18.9 & 0.96 & $(2)$ & 0.84 & $(2)$ & -0.13 \\
Norway & 17 & 17 & 25.0 & 23.7 & 0.70 & $(7)$ & 0.73 & $(7)$ & 0.03 \\
Portugal & 12 & 16 & 18.1 & 23.5 & 0.64 & $(11)$ & 0.69 & $(8)$ & 0.05 \\
Sweden & 26 & 21 & 34.6 & 32.2 & 0.75 & $(5)$ & 0.66 & $(9)$ & -0.08 \\
United Kingdom & 19 & 18 & 26.9 & 28.4 & 0.71 & $(6)$ & 0.63 & $(10)$ & -0.07 \\
United States & 10 & 9 & 23.7 & 26.1 & 0.41 & $(15)$ & 0.35 & $(16)$ & -0.06 \\
\hline Mean OECD-16 & 17.2 & 17.1 & 25.1 & 25.7 & 0.69 & & 0.67 & -0.02 \\
Mean EU15 & 19.2 & 17.9 & 28.4 & 28.6 & 0.68 & & 0.62 & -0.05 \\
Mean non-EU15 & 14.6 & 16.7 & 20.8 & 22.0 & 0.70 & & 0.76 & 0.06 \\
\hline
\end{tabular}

Source: OECD (2008, p. 141-142), SOCX (2008), and own calculations

The main message is that we find modest evidence for less targeting of social transfers and taxes in EU15 countries over time. For the 16 countries reported in Table 6, we find a significant relationship between levels of social expenditure and antipoverty effects of social transfers and taxes across countries for the year $1995\left(R^{2}=.38 ; p<.02\right)$, but the social expenditure variable becomes insignificant for $2005\left(R^{2}=.14 ; p>0.15\right)$. The effectives of (high) social spending on (high) antipoverty effects of social transfers and taxes faded away during last decade. Less targeting partly offers an explanation for higher poverty rates today than in 1995. Obviously, more factors should be taken into consideration (see Kim, 2000a; and Behrendt, 2002, OECD, 2008). Market income inequality is obviously an important source of cross-national variation in poverty. Also specific differences in both the social and the tax system should be taken into account in the assessment of the antipoverty effect of welfare states. Moreover, international variations in poverty profiles are driven by variations in socio-demographic and socio-economic structures, as these factors put different restraints on income transfer schemes. And also, besides social transfers, several other policy instruments may be used to alleviate poverty. For example, several countries put relatively much emphasis on improving job opportunities and stimulating labor force participation of lower income groups.

It should be noted that this paper focus on the antipoverty effect of social transfers and taxes. Obviously, changes of the antipoverty effect over time are the result of many factors. OECD (2008, p. 144-146) disentangled the total change over time in three components: the part due to changes in market-income poverty (keeping constant both the structure of the population and the effect of 
taxes and transfers in reducing poverty), the part due to changes in the effect of taxes and transfers in reducing market-income poverty (for a given population structure and market-rate poverty), and the part due to changes in the structure of the population (for a given marketincome poverty rate and level of effectiveness of tax and transfers in reducing poverty). The OECDstudy concludes that for most countries the largest part of changes in poverty rates for the period 1995-2005 can be attributed to net public transfers to households at the bottom of the income scale. Changes in the structure of the population dampened the rise of poverty rates in most countries, while the partial effect of changes in market-income poverty show much variation across countries during this period.

Overall, the trends of the components of post-tax-transfer poverty can be summarized as follows. In most of welfare states, pre-tax-transfer poverty has increased during the 1980s and early 1990s. Most countries have increased the size of the welfare state during the same period. However, in many cases, the increase in the size of the welfare state is not large enough to offset the increase in pre-tax-transfer poverty. As a result, post-tax-transfer poverty has also - more or less - increased in these countries (cf. Sainsbury and Morissens, 2002; Kim, 2000a; Smeeding, 2005). Changes in government redistribution dampened the rise in poverty in the decade from the mid-1980s to the mid-1990s, but reinforced it in the following one (cf. OECD, 2008, p. 148).

Minimum income policies do not lift people out of poverty nowadays. To illustrate this: Table 7 compares the generosity of net social assistance benefits for two family types among EU15 Member States. Compared to the official EU poverty line only Denmark, Finland, Ireland, and the Netherlands provide benefits adequate minimum income support. In four other countries (Austria, Germany, Sweden and the United Kingdom) benefits are close to being adequate, falling short about 10 percent of this poverty line. In all other countries benefits however drop more than 10 percent (Belgium, France, Luxembourg) and some times even more than 40 percent of the poverty line (Spain and Portugal).

Table 7: Adequacy of net social assistance in \% of poverty line, 2004

\begin{tabular}{l|cc|} 
& Single person & Lone parent \\
\hline Austria & 85 & 90 \\
Belgium & 76 & 89 \\
Denmark & 126 & 131 \\
Finland & 111 & 108 \\
France & 77 & 80 \\
Germany & 102 & 98 \\
Ireland & 121 & 105 \\
Luxembourg & 72 & 72 \\
Netherlands & 120 & 101 \\
Portugal & 48 & 83 \\
Spain & 55 & 57 \\
Sweden & 98 & 87 \\
United Kingdom & 96 & 105 \\
\hline Mean EU15 & 91.3 & 92.8 \\
\hline
\end{tabular}

Source: Cantillon, Van Mechelen, and Schulte (2008, p. 15)

\section{SOCIAL POLICY AREAS}

\subsection{Vulnerable groups: Decomposition of poverty by age groups}

An important critique on aggregated social expenditure data is that it is not possible to see which individual program is responsible for a specific dynamic. Therefore we show social expenditures for various programs. We look at two vulnerable age groups: children and the elderly. We present linkages of their poverty rates with social expenditures for social programs such as family and child benefits, and the public and private old age pensions and survivor schemes. Such social programs are supposed to guarantee a minimum income for those age groups typically over-represented among the poor. We are particularly interested in how the social transfers affect their poverty 
status. For each of the vulnerable groups, we report their poverty rates and then assess the impact of transfers and taxes on their poverty rates.

Figure 3 shows poverty profiles for children and elderly based on LIS and Eurostat. In order to account for different intensities of poverty, three different poverty lines are applied. Children and elderly are deemed to live in 'extreme poverty' households if their income remains below a poverty line of 40 percent of median equivalent income; a poverty line of 50 percent demarcates 'severe poverty', whereas households with an income between 40 and 50 percent of median equivalent income are considered as living in 'moderate poverty'. Households whose income exceeds the poverty line of 50 percent, but remains below 60 percent of median equivalent income are considered as living 'in poverty'. Countries are ranked according to their poverty rate at the 60 percent level of LIS in Figure 3; the shading of the bars shows different intensities of poverty or low income. Note that poverty indices from different sources vary and alter the country-ranking to some extent. ${ }^{21}$ Poverty data of LIS and Eurostat are pretty well correlated for children (around .9), while poverty data for the elderly show more variation (correlation coefficients range from .66 to .80 , depending on the poverty threshold applied).

On average, across all countries displayed, around 18 percent of all children fell below the 60 percent poverty threshold. Child poverty rates are especially low in the Nordic countries, where fewer than 10 percent of all children are poor. Child poverty is high in Mexico and the United States (around 30 percent), but also in Italy, Ireland, Spain and the United Kingdom, where it is above 20 percent. In most countries, relative poverty rates among children are also higher than for the entire population, but with much variation across countries. For example, in most Scandinavian countries poverty among children is even lower than that of total population, suggesting that families with children are relatively well protected against poverty (cf. Lelkes and Zólyomi, 2008, p. $5)$. These differences suggest that specific factors increase or decrease risks of poverty for children in OECD countries (cf. Förster and Mira d'Ercole, 2005).

21 The differences in methodology are minor. The concept of disposable income is quasi-identical between the three data sources (OECD, 2008, p. 153). The equivalence scale used by Eurostat differs only slightly from that used by the OECD and LIS, giving a somewhat higher weight to additional household members and distinguishing between adults and children. Eurostat uses the so-called "modified OECD" equivalence scale. This scale gives a weight of 1.0 to the first adult, 0.5 to any other household member aged 14 and over and 0.3 to each child. The resulting figure is attributed to each member of the household, whether adult or children. The equivalent size of a household that consists of 2 adults and 2 children below the age of 14 is therefore: $1.0+0.5+(2 * 0.3)=2.1$. Source: Eurostat $(2005$, p.63 $)$. 
Figure 3: Poverty rates children and elderly

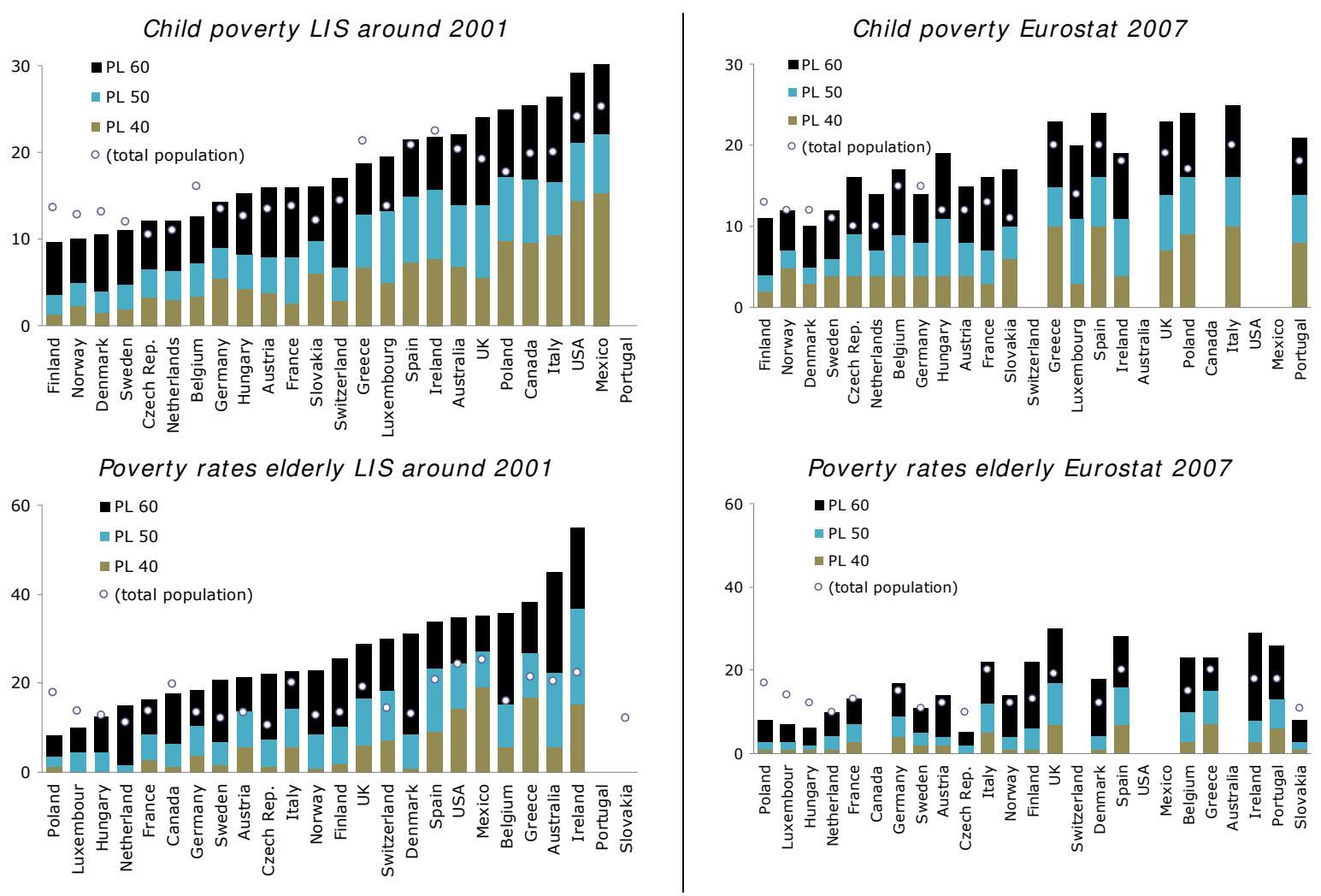

Note: Poverty rates are measured as the proportion of individuals with equivalized disposable income less than 40,50 and 60 percent of the median income of the entire population.

Source: LIS (2009), and Eurostat: ECHP/EU-SILC (2009)

Traditionally, also the elderly are seen as a vulnerable group, because their economic wellbeing largely depends on the social protection system. Data from LIS and from Eurostat do no tell the same story for the elderly when a poverty line of 60 percent is applied; much higher statistics for LIS-data. For example, LIS data presents a mean of 26.6 for EU15 countries, while Eurostat reports only 19.5 percent. Especially, Ireland is a special case: LIS reports that 55 percent of Irelands' elderly live at risk of poverty, while Eurostats' figure is hardly 29 percent.

Across all LIS-countries, poverty among elderly is on average 60 percent higher compared to total population. Cross-country differences are large, with relatively good figures for Poland, Luxembourg, Hungary and the Netherlands. In several countries poverty exceeds $1 / 3$ of the elderly - in Spain, the United States, Mexico, Belgium, Greece, Australia, Ireland and Slovakia.

To sum up, our analysis of poverty of vulnerable age-groups identifies serious holes in the safety net of several countries. In some member states the safety net offers little assistance to vulnerable groups (cf. Sainsbury and Morissens, 2002). On average, child poverty is a lesser problem than is the poverty of elderly in these nations. But single parents and their children generally have the highest poverty rates, while those in two-parent units, mixed units, and the childless experience the least poverty.

\subsection{Children}

In Finland and Denmark child poverty rate is around 10 percent (official EU-indictor), while over 20 percent of all children lives in poverty in Portugal, the United Kingdom, Greece, Spain and Italy. We calculate the absolute measures of poverty reduction through social transfers and taxes; see Figure 4, panel (a). The best-practices in 2007 are found in Austria, Sweden, Ireland and Finland with antipoverty effects over 20 percent points. Greece, Spain, Portugal and Italy produce rather poor antipoverty effects for children with their tax/transfer system (below 10 percent points). The 
picture in panel (b) is similar, although we find little higher antipoverty effects for all countries when retirement and survivor's pensions are considered as transfers.

Figure 4: Antipoverty effect of social transfers and taxes 0-15 years among EU15, 2007

Panel (a)

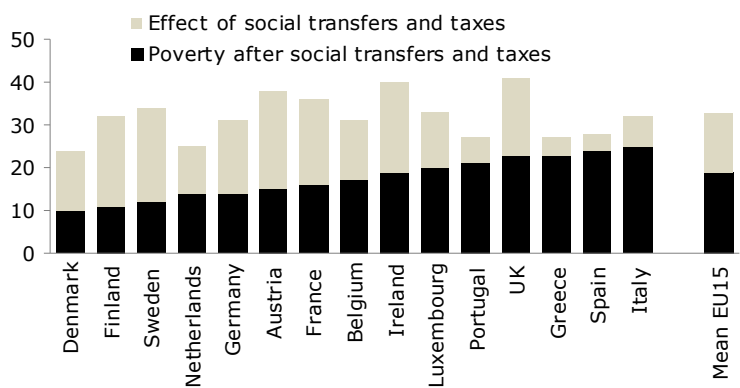

Panel (b)

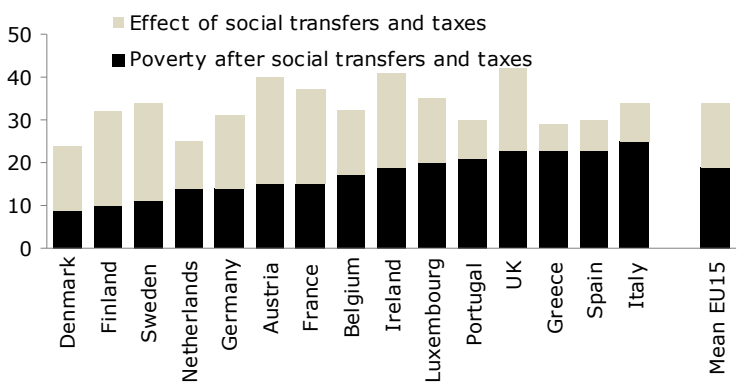

Notes:

- Panel (a) Pensions are included in social transfers in at risk of poverty rates before social transfers

- Panel (b) Pensions are excluded from social transfers in at risk of poverty rates before social transfers

Source: Eurostat: ECHP/EU-SILC (2009), SOCX (2008), and own calculations

The OECD Social Expenditure Database (SOCX) includes internationally comparable statistics on gross public and private social expenditure at program level. SOCX registers also family programs, i.e. expenditure which supports families (excluding one-person households). This expenditure is often related to the costs associated with raising children or with the support of other dependants. Table 8 presents the linkage between poverty reduction through the tax/transfer system, and social expenditure for family programs for EU15 countries. This gives a picture of the targeting effectiveness of combating child poverty across European countries. However, the earlier disclaimer applies: the ranking of the countries can be influenced by country specific cyclical factors due the data year 2005-2007 chosen (relatively low/high social expenditures). 
Table 8: Targeting effect of social expenditures for family programs on poverty reduction of children in EU15, around 2005-2007

\begin{tabular}{|c|c|c|c|c|c|c|c|c|}
\hline & \multicolumn{3}{|c|}{$\begin{array}{l}\text { Poverty rate } 0-15 \text { years (PL } \\
60) \text { before and after social } \\
\text { transfers and taxes, } 2007\end{array}$} & \multicolumn{2}{|c|}{$\begin{array}{c}\text { Effect of social } \\
\text { transfers and taxes }\end{array}$} & \multirow{3}{*}{$\begin{array}{l}\text { Gross social } \\
\text { expenditure } \\
\text { on family } \\
\text { programs, \% } \\
\text { GDP, } 2005 \\
\text { (6) }\end{array}$} & \multicolumn{2}{|c|}{ Targeting effect } \\
\hline & $\begin{array}{l}\text { Before } \\
\text { pensions } \\
\text { excluded }\end{array}$ & $\begin{array}{c}\text { Before } \\
\text { pensions } \\
\text { included }\end{array}$ & After & $(1)-(3)$ & $(2)-(3)$ & & $(4):(6)$ & $(5):(6)$ \\
\hline & $(1)$ & (2) & (3) & (4) & (5) & & $(7)$ & $(8)$ \\
\hline Austria & 38 & 40 & 15 & 23 & 25 & 2.8 & 8.2 & 8.9 \\
\hline Belgium & 31 & 32 & 17 & 14 & 15 & 2.6 & 5.4 & 5.8 \\
\hline Denmark & 24 & 24 & 9 & 15 & 15 & 3.2 & 4.7 & 4.7 \\
\hline Finland & 32 & 32 & 10 & 22 & 22 & 3.0 & 7.3 & 7.3 \\
\hline France & 36 & 37 & 15 & 21 & 22 & 3.0 & 7.0 & 7.3 \\
\hline Germany & 31 & 31 & 14 & 17 & 17 & 2.3 & 7.4 & 7.4 \\
\hline Greece & 27 & 29 & 23 & 4 & 6 & 1.1 & 3.6 & 5.5 \\
\hline Ireland & 40 & 41 & 19 & 21 & 22 & 2.5 & 8.4 & 8.8 \\
\hline Italy & 32 & 34 & 25 & 7 & 9 & 1.4 & 5.0 & 6.4 \\
\hline Luxembourg & 33 & 35 & 20 & 13 & 15 & 3.6 & 3.6 & 4.2 \\
\hline Netherlands & 25 & 25 & 14 & 11 & 11 & 1.6 & 6.9 & 6.9 \\
\hline Portugal & 27 & 30 & 21 & 6 & 9 & 1.2 & 5.0 & 7.5 \\
\hline Spain & 28 & 30 & 23 & 5 & 7 & 1.1 & 4.5 & 6.4 \\
\hline Sweden & 34 & 34 & 11 & 23 & 23 & 3.2 & 7.2 & 7.2 \\
\hline United Kingdom & 41 & 42 & 23 & 18 & 19 & 3.2 & 5.6 & 5.9 \\
\hline Mean EU15 & 33 & 34 & 19 & 14 & 15 & 2.4 & 5.9 & 6.3 \\
\hline
\end{tabular}

- (a) Pensions are excluded from social transfers in at risk of poverty rates before social transfers

- (b) Pensions are included in social transfers in at risk of poverty rates before social transfers

Source: Eurostat: ECHP/EU-SILC (2009), SOCX (2008), and own calculations

Rather good targeting figures of child poverty alleviation per point of GDP social spending on family programs are found in Ireland, followed by Austria, Germany, Finland and Sweden. Low scores for Luxembourg, Greece, Spain and Denmark. In these countries each percentage point GDP spent for family programs alleviates poverty only by 3.6-4.7 percentage points around 2005-2007.

Within the group of EU15 countries we do find a significant relationship between (high) levels of gross total social expenditure on family programs in 2005 and (high) antipoverty effects of social transfers and taxes for children in $2007\left(R^{2}=0.63 ; \rho<.01\right)$. Obviously this result does not depend on the way pensions are treated (as primary income or as transfers). See Figure 5.

Figure 5: Linkage between gross total social expenditure on family programs and relative poverty rate reduction among children in EU15-countries, around 2005-2007
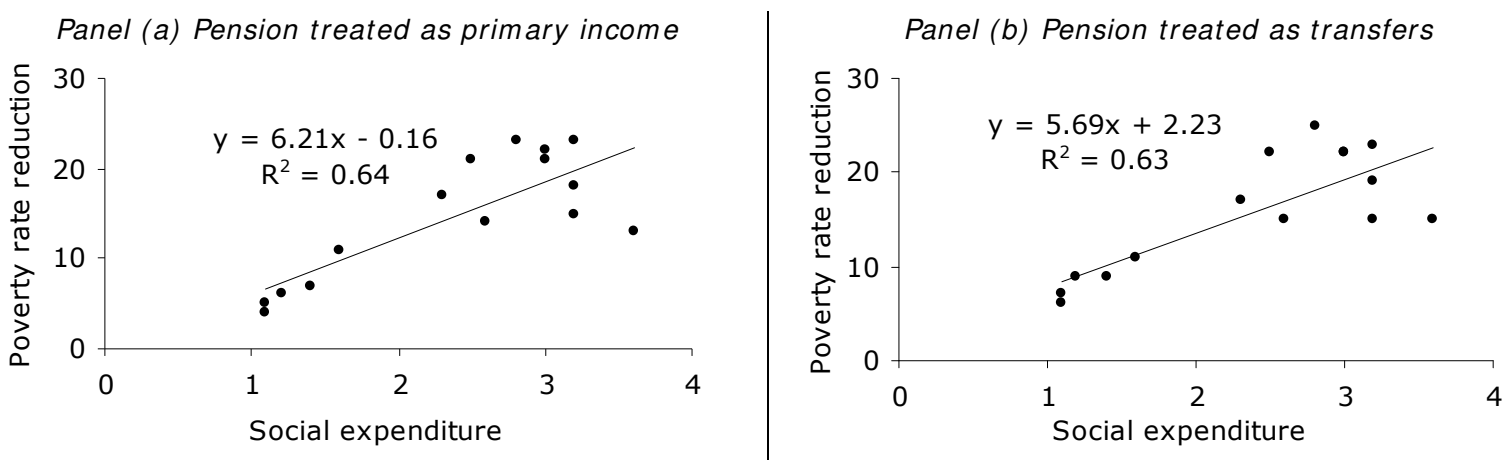

Source: Eurostat: ECHP/EU-SILC (2009), SOCX (2008), and own calculations 
Data for 1995 tell more or less the same story: a strong positive linkage between levels of social expenditure for family programs and antipoverty effects of social transfers and taxes for children. This relationship became even somewhat stronger during the past decade (higher correlation coefficients and lower $\rho$-values) probably under the influence of targeting family programs further towards those children in need. See the Appendix for details.

Next, we also include ten non-EU15 countries into our analysis. Poverty rates are from LIS (around 2001), and a 60-percent-of-median-income poverty threshold is applied. For all countries, we find a significant negative relationship between levels of social expenditure on family programs and poverty rates $\left(R^{2}=.32 ; \rho<.01\right)$. This correlation is much stronger for non-EU15 countries $\left(R^{2}=.50\right)$ compared with the EU15 countries $\left(R^{2}=.12\right)$. See Figure 6 .

Figure 6: Linkage between gross total social expenditure on family programs and LIS poverty rates among 24 countries, around 2001-2005

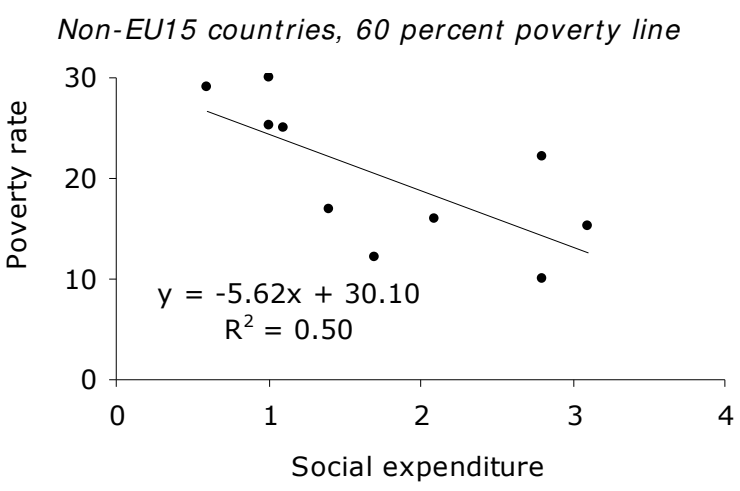

Non-EU15 countries: Australia, Canada, Czech Republic, Hungary, Mexico, Norway, Poland, Slovakia, Switzerland and the United States

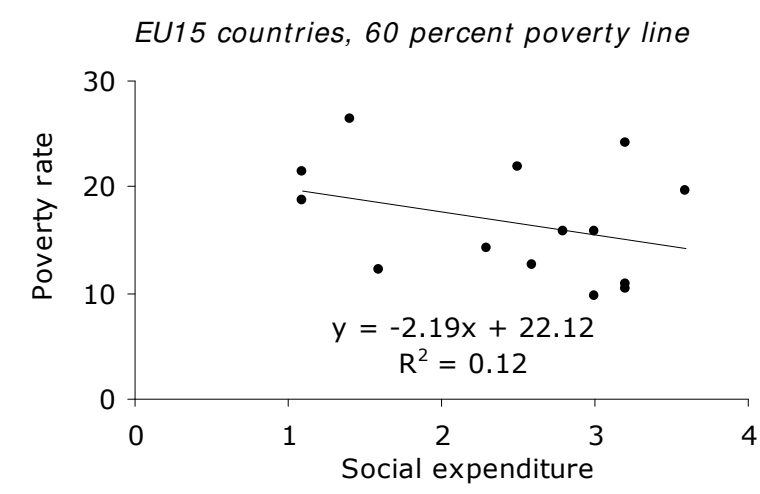

EU15 countries: Austria, Belgium, Denmark, Finland, France, Germany, Greece, Ireland, Italy, Luxembourg, Netherlands, Spain, Sweden and the United Kingdom

Source: LIS (2009), SOCX (2008), and own calculations

This result across countries is rather robust over time, and is independent of poverty lines applied $(40,50$ or 60 percent threshold) or the data source used for child poverty rates (LIS or OECD). Our Appendix presents the linkage between poverty rates for children and social expenditure for family programs for all countries where all relevant data items are available around 1985, 1995 and 2005. For all data years, we find a strong negative relationship, however, this relationship much stronger for non-EU15 countries compared to EU15 countries.

\subsection{Elderly}

In most EU15 countries, relative poverty rates among elderly are much higher than for the entire population or for children, but with much variation across countries. In Luxembourg and the Netherlands poverty among the elderly is below 10 percent (official EU-indictor), while over a quarter of all elderly lives in poverty in Ireland, Portugal, Spain and in the United Kingdom. These differences suggest that specific factors increase risks of poverty for elderly in some EU-countries. We calculate the absolute measures of poverty reduction through social transfers and taxes. It should be stressed that the effectiveness of combating poverty among the elderly across countries is highly sensitive for the way pensions are treated. Given their weight in the disposable income of elderly people, pensions play a major role in shaping income adequacy and poverty risks for this group of the population. When pension is considered as primary income, the antipoverty effect of transfers and taxes among elderly in EU15 amounts 4 percent points on average. However, in case pensions are excluded from social transfers we find much higher figures for the antipoverty effect of transfers (and taxes) across EU15 countries: 69 percent points on average!

Figure 7, panel (a) presents the best-practices for 2007 to be found in Denmark, Ireland and Sweden with antipoverty effects above 10 percent points. Germany and Italy produce rather poor antipoverty effects for elderly with their tax/transfer system (below 3 percent points). Obviously 
the picture in panel (b) shows much higher antipoverty effects for all countries when retirement and survivor's pensions are excluded from primary income, now presenting antipoverty effects of over 80 points for the Netherlands, followed by Sweden, Luxembourg and France. ${ }^{22}$

Figure 7: Antipoverty effect of social transfers and taxes elderly among EU15, 2007

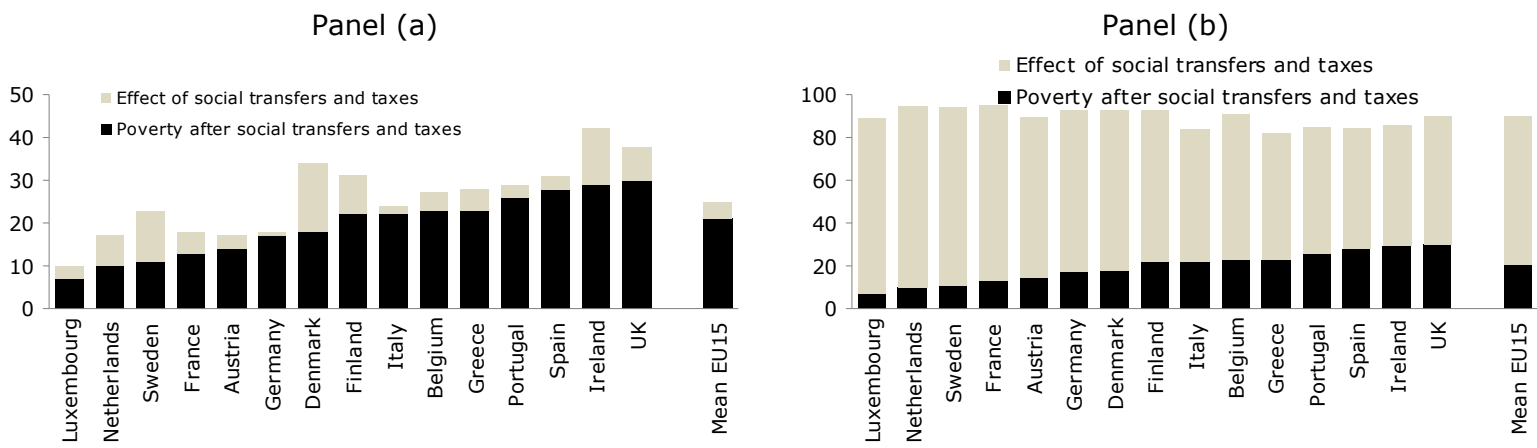

Notes:

- Panel (a) Pensions are included in social transfers in at risk of poverty rates before social transfers

- Panel (b) Pensions are excluded from social transfers in at risk of poverty rates before social transfers

- In all cases the risk-of-poverty threshold is set at 60 percent of median equivalized disposable income.

Source: Eurostat: ECHP/EU-SILC (2009), and own calculations

Again, we use the OECD Social Expenditure Database. SOCX contains gross total social expenditures both on public old age programs (pensions) and on survivor schemes. ${ }^{23}$ Table 9 presents the linkage between poverty reduction through the tax/transfer system, and social expenditure for public and private old age pensions and survivors schemes for EU15 countries. This gives a picture of the targeting effectiveness of combating poverty among elderly across European countries. However, the earlier disclaimer applies: the ranking of the countries can be influenced by country specific cyclical factors due the data year 2005-2007 chosen (relatively low/high social expenditures).

$22 \mathrm{Wu}$ (2005) indicate that without social old age and survivors programs more than half of the older persons would be in poverty. His figure is much lower than ours for EU15. Wu's analyses are based on LIS-data for 15 selected OECD countries; a 50-percent-of-median-income poverty threshold is applied. Lefèbvre (2007, p. 13) shows much higher figures based on LIS-data (PL 50), ranging from 54 percent for Finland to over 90 percent for Austria, Belgium, Estonia, France, Hungary, Luxembourg, Spain and Slovenia.

23 Old-age: comprises all cash expenditures (including lump-sum payments) on old-age pensions. Old-age cash benefits provide an income for persons retired from the labor market or guarantee incomes when a person has reached a 'standard' pensionable age or fulfilled the necessary contributory requirements. This category also includes early retirement pensions: pensions paid before the beneficiary has reached the 'standard' pensionable age relevant to the program. Excluded are programs concerning early retirement for labor market reasons which are classified under unemployment. Old-age includes supplements for dependants paid to old-age pensioners with dependants under old-age cash benefits. Old age also includes social expenditure on services for the elderly people, services such as day care and rehabilitation services, home-help services and other benefits in kind. It also includes expenditure on the provision of residential care in an institution (for example, the cost of operating homes for the elderly).

Survivors: many countries have social expenditure programs in the public sphere which provide the spouse or dependent of a deceased person with a benefit (either in cash or in kind). Expenditure in this policy area has been grouped under survivors. Allowances and supplements for dependent children of the recipient of a survivors'benefit are also recorded here. 
Table 9: Targeting effect of social expenditures for old age pension programs and survivors schemes on poverty reduction of elderly in EU15, around 2005-2007

\begin{tabular}{|c|c|c|c|c|c|c|c|c|}
\hline & \multicolumn{3}{|c|}{$\begin{array}{c}\text { Poverty rate } 65 \text { years and } \\
\text { over (PL 60) before and after } \\
\text { social transfers and taxes, } \\
2007\end{array}$} & \multicolumn{2}{|c|}{$\begin{array}{c}\text { Effect of social } \\
\text { transfers and taxes }\end{array}$} & \multirow[t]{2}{*}{$\begin{array}{l}\text { Gross social } \\
\text { expenditure } \\
\text { on OAP + } \\
\text { survivors } \\
\text { programs, \% } \\
\text { GDP, } 2005 \\
(6) \\
\end{array}$} & $(4):(6)$ & g effect \\
\hline & (1) & (2) & (3) & (4) & (5) & & (7) & $(8)$ \\
\hline Austria & 17 & 89 & 14 & 3 & 75 & 13.5 & 0.2 & 5.6 \\
\hline Belgium & 27 & 91 & 23 & 4 & 68 & 11.9 & 0.3 & 5.7 \\
\hline Denmark & 34 & 93 & 18 & 16 & 75 & 9.4 & 1.7 & 8.0 \\
\hline Finland & 31 & 93 & 22 & 9 & 71 & 9.6 & 0.9 & 7.4 \\
\hline France & 18 & 95 & 13 & 5 & 82 & 13.0 & 0.4 & 6.3 \\
\hline Germany & 18 & 93 & 17 & 1 & 76 & 12.3 & 0.1 & 6.2 \\
\hline Greece & 28 & 82 & 23 & 5 & 59 & 12.0 & 0.4 & 4.9 \\
\hline Ireland & 42 & 86 & 29 & 13 & 57 & 4.5 & 2.9 & 12.7 \\
\hline Italy & 24 & 84 & 22 & 2 & 62 & 15.4 & 0.1 & 4.0 \\
\hline Luxembourg & 10 & 89 & 7 & 3 & 82 & 7.6 & 0.4 & 10.8 \\
\hline Netherlands & 17 & 95 & 10 & 7 & 85 & 9.3 & 0.8 & 9.1 \\
\hline Portugal & 29 & 85 & 26 & 3 & 59 & 10.5 & 0.3 & 5.6 \\
\hline Spain & 31 & 84 & 28 & 3 & 56 & 8.4 & 0.4 & 6.7 \\
\hline Sweden & 23 & 94 & 11 & 12 & 83 & 12.2 & 1.0 & 6.8 \\
\hline United Kingdom & 38 & 90 & 30 & 8 & 60 & 11.0 & 0.7 & 5.5 \\
\hline Mean EU15 & 25 & 90 & 21 & 4 & 69 & 10.7 & 0.4 & 6.4 \\
\hline
\end{tabular}

- (a) Pensions are excluded from social transfers in at risk of poverty rates before social transfers

- (b) Pensions are included in social transfers in at risk of poverty rates before social transfers

Source: Eurostat: ECHP/EU-SILC (2009), SOCX (2008), and own calculations

Rather good targeting figures of poverty alleviation per point of GDP social spending on pension programs and survivors schemes are found for Ireland, followed by Denmark and Sweden. Low scores for Germany, Italy, Austria, Portugal and Belgium. In these countries each percentage point GDP spent for pension programs and survivors schemes alleviates poverty only by .1-.3 percentage points around 2005-2007.

Within the group of EU15 countries there is ample evidence for a relationship between (high) levels of gross total social expenditure on old age pension programs and survivors schemes in 2005 and (high) antipoverty effects of social transfers and taxes for elderly in 2007 ( $\rho>.93$ ), independent of the way pensions are treated (as primary income or as transfers). A similar analysis for the year 1995 points in the same direction: such a relationship does not exist (see the Appendix for details). Finally we include ten non-EU15 countries into our analysis. Poverty rates among the elderly are taken from LIS (around 2001), and a 60-percent-of-median-income poverty threshold is applied. We do not find a (negative) relationship between levels of social expenditure on old age pension and survivors schemes and the level of poverty rates across the 24 developed countries $\left(R^{2}=.13\right)$. This weak correlation is found for both the group of EU15 countries $\left(R^{2}=.18\right)$ and the group of nonEU15 countries $\left(R^{2}=.15\right)$. Despite relatively high gross public and private spending on old-age pensions and survivors schemes some countries experience relatively high poverty rates among the elderly, especially in Greece. Ireland is a special case in LIS with 55 percent of elderly living at risk of poverty in case the 60 percent threshold is applied, probably as a consequence of only spending 4.5 percent of GDP for old age pension programs and survivors schemes. Rather good figures are found for Luxembourg, the Netherlands and Canada. In these countries relatively low poverty rates among the elderly are combined with relatively low gross public and private social expenditure on old age and survivors. 
Figure 8: Linkage between gross social expenditure on old age and survivors programs and LIS poverty rates among 24 countries, around 2001-2005

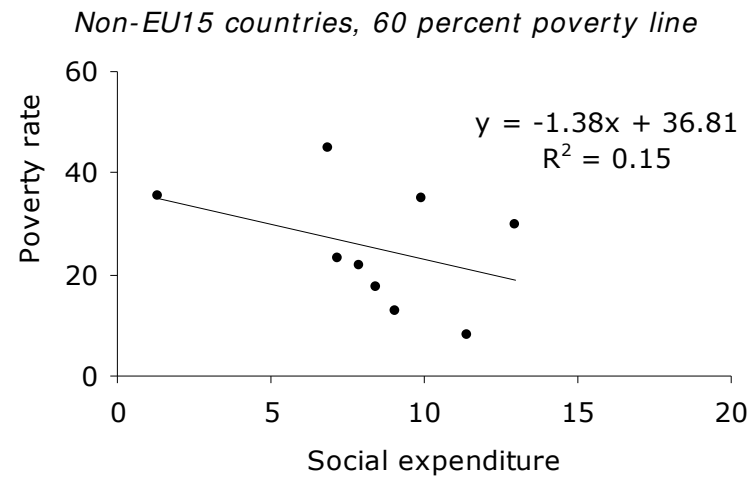

Non-EU15 countries: Australia, Canada, Czech Republic, Hungary, Mexico, Norway, Poland, Switzerland and the United States

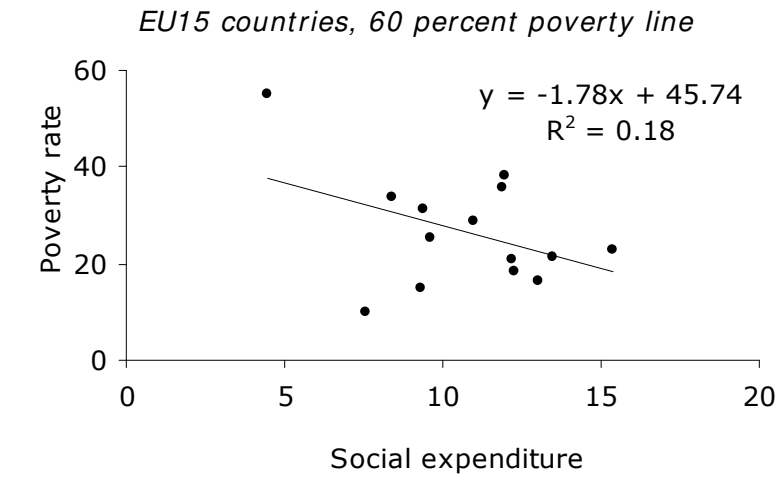

EU15 countries: Austria, Belgium, Denmark, Finland, France, Germany, Greece, Ireland, Italy, Luxembourg, Netherlands, Spain, Sweden and the United Kingdom

Source: LIS (2009), SOCX (2008), and own calculations

Also, this result across countries is rather robust over time and is independent of different poverty lines applied or the data source used for poverty rates. Our Appendix presents the linkage between poverty rates for elderly 65 years and over and social expenditure for pension programs and survivors schemes for all countries where all relevant data items are available around 1985, 1995 and 2005. For all data years we do not find any significant relationship, independent of the countries included - EU15 countries and non-EU15 countries - in the sample. See the Appendix for details.

\section{CONCLUSION}

Poverty alleviation is an important objective of the EU. A wide variety of poverty rates are be found within Europe. Some countries are more effective in poverty reduction than other countries. Remarkably, average at-risk-of-poverty rates - an official EU social cohesion indicator - have risen since the adoption of the Lisbon Agenda. This suggests that recent EU-initiatives regarding combating poverty are not very effective yet. Obviously, several policy strategies may be chosen to combat poverty. This paper analyzes the effect of social transfer policies on poverty alleviation.

We analyzed the reduction of poverty rates through taxes and transfers (the difference between poverty rates calculated for market incomes and poverty rates calculated for disposable incomes) and its relationship to welfare state efforts. Within the group of EU15 countries, we do not find a significant relationship between (high) levels of social expenditure and (high) antipoverty effects of social transfers and taxes in case pension is earmarked as primary income. This picture alters severely when pensions are treated as transfers. In that case the relationship between social expenditures and antipoverty effects of social transfers and taxes across countries becomes significant. So, social spending seems to be an important determinant of a country's poverty outcome, especially among the elderly, when pensions are considered as transfers.

Our analysis highlights some cross-country differences in targeting of social expenditures on poverty alleviation in EU15 and non-EU15 countries around 2005. We provide an indicator of Public Policy Effectiveness on Poverty Alleviation across countries. Each percentage point of social expenditure alleviates poverty in both EU15 and non-EU15 on average by .7 percentage points. Relatively high scores in EU15 countries are found for Ireland and the Scandinavian countries, while Italy, Greece and Spain score lowest. Outside Europe the poorest scores are reported for Korea and the United States. Remarkably, country ranking is rather stable over time when outcomes for 1995 and 2005 are compared, although some of our results may be sensitive to cyclical factors. Finally, we analyzed poverty among vulnerable age groups. Our results show that family programs and child support alleviate poverty among children to a large extent, especially in 
non-EU15 countries. For public and private old age pension and survivors schemes we find no effect on poverty in case pensions are considered as transfers (both in EU15 and non-EU15 countries). However, this picture changes completely when pensions are counted as transfers. In that case the poverty rate among elderly in EU15 falls from 90 percent to 21 percent through taxes and social transfers! 


\section{REFERENCES}

Adema, W. (2001), 'Net Social Expenditure: $2^{\text {nd }}$ edition', Labour Market and Social Policy Occasional Papers, No. 52, Paris: OECD.

Adema, W., and M. Ladaique (2005), 'Net Social Expenditure, 2005 edition', OECD Social, Employment and Migration Working Paper 29, Paris: OECD.

Atkinson, A.B. (1987), 'On the measurement of poverty', Econometrica 55 (4), pp. 749-764.

Atkinson, T. (2002), 'Social Inclusion and the European Union', Journal of Common Market Studies 40 (4), pp. 625-643.

Atkinson, A.B. (2003), 'Income Inequality in OECD Countries: Data and Explanations', CESifo Economic Studies 49(4), pp. 479-513.

Atkinson, A.B., L. Rainwater and T.M. Smeeding (1995), 'Income Distribution in OECD Countries: Evidence from the Luxembourg Income Study', OECD Social Policy Studies 18, Paris.

Atkinson, A.B., and A. Brandolini (2001), 'Promise and Pitfalls in the Use of Secondary Data-Sets: Income Inequality in OECD Countries as a Case Study', Journal of Economic Literature 39 (3) (September), pp. 771-800.

Atkinson, T., B. Cantillon, E. Marlier and B. Nolan (2002), Social Indicators. The EU and Social Inclusion, Oxford: University Press.

Beblavy, M. (2009), 'Comparative analysis of determinants and effects of social protection spending in the new EU member states', paper presented at FISS Conference, June 16th18th, Sigtuna, Sweden.

Behrendt, Ch. (2000), 'Is there income poverty in Western Europe? Methodological pitfalls in the measurement of poverty in a comparative perspective', Luxembourg Income Study Working Paper Series 258, Luxembourg.

Behrendt, Ch. (2002), 'Holes in the safety net? Social security and the alleviation of poverty in a comparative perspective', in: R. Sigg and Chr. Behrendt (eds.) Social Security in the Global Village, International Social Security Series, Volume 8, New Brunswick / London: Transaction Publishers, pp. 333-358.

Bourguignon, F., and L. Pereira da Silva and N. Stern (2002), 'Evaluating the Poverty Impact of Economic Policies: Some Analytical Challenges', Stern - Washington DC: The World Bank (Mimeo), 2002.

Brandolini, A. (2006), 'Measurement of income distribution in supranational entities: The case of the European Union', Luxembourg Income Study Working Paper Series 452, Luxembourg.

Brandolini, A., and T.M. Smeeding (2007), 'Inequality Patterns in Western-Type Democracies: Cross-Country Differences and Time Changes', Luxembourg Income Study Working Paper Series 458, Luxembourg

Brandolini, A., and T.M. Smeeding (2008), 'Inequality: International Evidence', in: S.N. Durlauf and L.E. Blume (eds.), The New Palgrave Dictionary of Economics, Basingstoke: Palgrave Macmillan, pp. 1013-1021.

Caminada, K. and K.P. Goudswaard (2001), 'International Trends in Income Inequality and Social Policy', International Tax and Public Finance 8 (4), pp. 395-415.

Caminada, K. and K.P. Goudswaard (2005), 'Are Public and Private Social Expenditures Complementary?', International Advances in Economic Research 11 (2), pp. 175-189.

Caminada, K. and K.P. Goudswaard, K.P. (2010), 'Social income transfers and poverty alleviation in the EU15 and other OECD countries. An empirical analysis', Research Memorandum Department of Economics, Leiden University, (forthcoming).

Cantillon, B. (2009), 'Poverty and social security: the paradox of the social investment state in the rich egalitarian EU member states', paper presented at FISS Conference, June 16th-18th, Sigtuna, Sweden. 
Cantillon, B., N. Van Mechelen and B. Schulte (2008), 'Minimum income policies in old and new member states', in: J. Alber, T. Fahey and C. Saraceno (eds.), Handbook of Quality of Life in the Enlarged European Union, London: Routledge, pp. 218-234.

Danziger, S., R. Haveman and R. Plotnick (1981), 'How Income Transfer Programs Affect Work, Savings and Income Distribution: A Critical Assessment', Journal of Economic Literature 19 (September), pp. 975-1028.

European Commission (2007), Joint Report on Social protection and social inclusion 2007. Social inclusion, pensions, healthcare and long term care, Luxembourg: Office for Official Publications of the European Communities.

European Commission (2008), Joint Report on Social protection and social inclusion 2008. Social inclusion, pensions, healthcare and long term care, Luxembourg: Office for Official Publications of the European Communities.

European Commission (2009), Joint Report on Social protection and social inclusion 2009, Brussels: European Commission, Directorate-General for Employment, Social Affairs and Equal Opportunities.

European Commission - Eurostat (2008), The Social Situation in the European Union 2007. Social Cohesion through Equal Opportunities, Luxembourg: Office for Official Publications of the European Communities.

Eurostat (2005), 'The continuity of indicators during the transition between ECHP and EU-SILC', Working Paper and Studies, Eurostat.

Eurostat (2009), Structural Indicators EU - Social Cohesion (http://epp.eurostat.ec.europa.eu/).

Esping-Andersen, G., and J. Myles (2009), 'Economic Inequality and the Welfare State', in: W. Salverda, B. Nolan and T.M. Smeeding (eds.), The Oxford Handbook of Economic Inequality, Oxford: University Press, pp. 639-664.

Förster, M. (1993), 'Comparing Poverty in 13 OECD Countries: Traditional and Synthetic Approaches', Luxembourg Income Study Working Paper 100, Luxembourg.

Förster, M., and M. Pearson (2002), 'Income distribution and poverty in the OECD area: trends and driving forces', OECD Economic Studies, No. 34, 2002/1, Paris: OECD, pp. 7-39.

Förster, M., and M. Mira d'Ercole (2005), 'Income Distribution and Poverty in OECD Countries in the Second Half of the 1990s', OECD Social, Employment and Migration Working Papers, no. 22.

Gottschalk, P., and T.M. Smeeding (1997), 'Cross-National Comparisons of Earnings and Income Inequality', Journal of Economic Literature 35 (June), pp. 633-687.

Gottschalk, P. and T.M. Smeeding (2000), 'Empirical Evidence on Income Inequality in Industrialized Countries', in: A.B. Atkinson and F. Bourgignon (eds), Handbook of Income Distribution, New York: Elsevier-North Holland Publishers, pp. 261-308.

Guio, A.-C. (2005), 'Income poverty and social exclusion in the EU25', Statistics in focus: population and social conditions, 13/2005, pp. 1-7.

Hagenaars, A., and K. de Vos (1987), 'The definition and measurement of poverty', The Journal of Human Resources 23 (2), pp. 211-221.

Haveman, R. (2008), 'What Does It Mean to Be Poor in a Rich Society?', Institute for Research on Poverty Discussion Paper 1356-08, Madison.

Kakwani, N., and J. Silber (eds.) (2007), The Many Dimensions of Poverty, New York: Palgrave Macmillan.

Kakwani, N., and J. Silber (eds.) (2008), Quantitative Approaches to Multidimensional Poverty Measurement, New York: Palgrave Macmillan.

Kenworthy, L. (1999), 'Do Social Welfare Policies Reduce Poverty? A Cross-National Assessment', Social Forces 77 (3), pp. 1119-1139.

Kim, H. (2000a), 'Anti-Poverty Effectiveness of Taxes and Income Transfers in Welfare States', International Social Security Review 53 (4), pp. 105-129. 
Kim, H. (2000b), 'Do welfare states reduce poverty? A critical shortcoming in the standard analysis of the anti-poverty effect of welfare states', Luxembourg Income Study Working Paper Series 233, Luxembourg.

Kühner, S. (2007), 'Country-Level Comparisons of Welfare State Change Measures: Another Facet of the Dependent Variable Problem within the Comparative Analysis of the Welfare State?', Journal of European Social Policy 17 (1), pp. 5-18.

Leibfried, S. (2002), 'Some Background Comments on the Extension of the Open Method of Coordination', Belgisch Tijdschrift voor Sociale Zekerheid 44 (3), pp. 473-479.

Lefèbvre, M. (2007), 'The Redistributive Effects of Pension Systems in Europe: A Survey of Evidence', Luxembourg Income Study Working Paper Series 457, Luxembourg.

Lelkes, O., and E. Zólyomi (2008), 'Poverty Across Europe: The Latest Evidence Using the EU-SILC Survey', European Centre Policy Brief, October 2008, pp. 1-15.

Luxembourg Income Study (2009), LIS Key Figures on Poverty, Luxembourg (www.lisproject.org).

Mahler, V.A., and D.K. Jesuit (2006), 'Fiscal Redistribution in the Developed Countries: New Insights from the Luxembourg Income Study', Socio-Economic Review 4, pp. 483-511 (an extended version is published as Luxembourg Income Study Working Paper Series 392, Luxembourg).

Marcus, J. and S. Danziger (2000), 'Income Poverty in Advanced Countries', in: A.B. Atkinson, and Bourguignon, F. (eds.), Handbook of Income Distribution, New York: Elsevier-North Holland Publishers.

Musgrave, R.A., K.E. Case and H.B. Leonard, (1974), 'The Distribution of Fiscal Burdens and Benefits', Public Finance Quarterly 2 (July), pp. 259-311.

Notten, G., and C. de Neuborg (2007), 'Relative or absolute poverty in the US and EU? The battle of the rates', MPRA Working Paper 5313, Munich.

Nell, G. (2005), 'Prosperity and the welfare state: The effect of benefit generosity and wage coordination on absolute poverty and prosperity in cross-national perspective', Luxembourg Income Study Working Paper Series 424, Luxembourg.

OECD (2008), Growing unequal? Income distribution and Poverty in OECD Countries, Paris: OECD.

Ringen, S. (1987), The Possibility of Politics, Oxford: Clarendon Press.

Sainsbury, D., and A. Morissens (2002), 'European anti-poverty policies in the 1990s: Toward a common safety net', Luxembourg Income Study Working Paper Series 307, Luxembourg.

Scholz, J.K., R. Moffitt, and B. Cowan (2008), 'Trends in Income Support', Institute for Research on Poverty Discussion Paper 1350-08, Madison.

Smeeding, T. (2005), 'Poor people in rich nations: The United States in comparative perspective', Luxembourg Income Study Working Paper Series 419, Luxembourg.

Smeeding, T., L. Rainwater, and G. Burtless (2000), 'United States Poverty in a Cross-National Context', Luxembourg Income Study Working Paper Series 244, Luxembourg.

Smolensky, E., W. Hoyt and S. Danziger (1987), 'A Critical Survey of Efforts to Measure Budget Incidence', in: H.M. van de Kar; B.L. Wolfe (eds.), The Relevance of Public Finance for Policy-Making, Proceedings IIFP Congress 1985, Detroit, pp. 165-179.

SOCX OECD (2008), Social Expenditure Database 1980-2005 (www.oecd.org/els/social/expenditure).

Thorbecke, E. (2007), 'Multidimensional Poverty: Conceptual and Measurement Issues' in: N. Kakwani and J. Silber (eds.), The Many Dimensions of Poverty, New York: Palgrave Macmillan, pp. 3-19.

Wu, K. (2005), 'How Social Security Keeps Older Persons Out of Poverty across Developed Countries', Luxembourg Income Study Working Paper 410, Luxembourg. 


\section{APPENDIX: DATA AND CORRELATION TESTS ACROSS COUNTRIES}

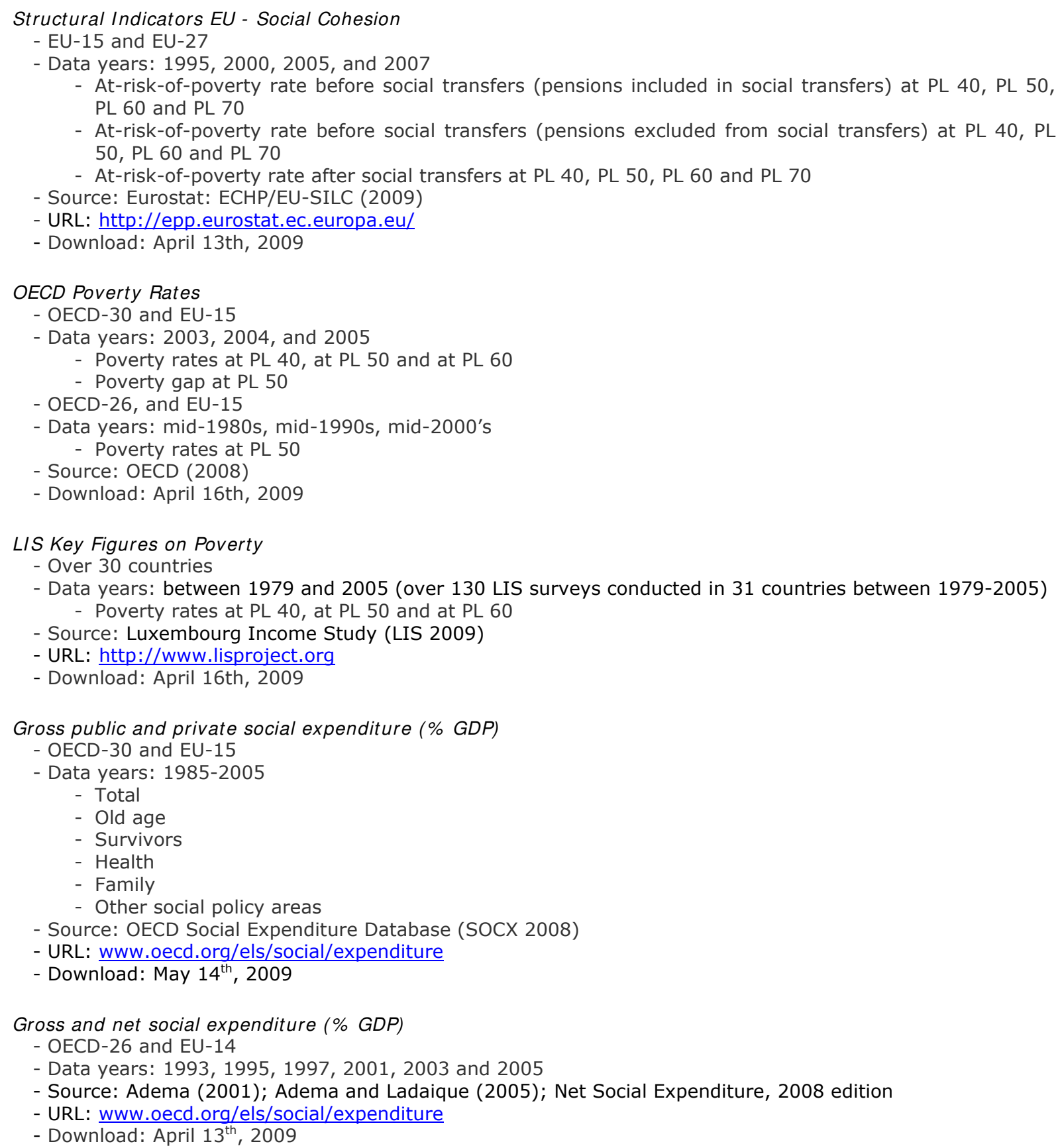




\section{CORRELATION TESTS ACROSS COUNTRIES}

We regress the level of poverty rates across countries with the level of social expenditure as percentage of GDP. The coefficient is estimated using a linear ordinary least square regression model of cross-sectional data of the following form:

$$
Y_{i, t}=A+\beta X_{i, t}+u_{i}
$$

The term on the left-hand side of equation (1) is the level of the poverty indicator of country $i$ at time-period $t$. The level of social expenditure as percentage of GDP in country $i$ at period $t$ is given by $\mathrm{X}_{\mathrm{i}}, t$, and $\mathrm{u}_{\mathrm{i}}$ is a disturbance term. If the coefficient $\beta$ is negative, we say that social expenditures alleviate poverty across countries. $A$ is a constant term across countries. The higher the value of $\beta$, the stronger will be the antipoverty effect of an additional point of GDP spend on social expenditure. The results are presented below.

\section{A1: TARGETING EFFECT OF SOCIAL EXPENDITURES ON POVERTY REDUCTION (OECD PL 50), 2005-2007}

We present the linkage between the reduction in poverty rates as result of social transfers and taxes, and social expenditure for both EU15 and non-EU15 countries. For all countries, we do not find a significant relationship between (high) levels of total social expenditure and (high) antipoverty effects of social transfers and taxes, independent of applying net or gross social indicators. When we exclude health expenditure, the social expenditure variable becomes significant. Furthermore, the net social expenditure variable is significant in case we only include EU15 countries in our sample.

\begin{tabular}{l|ccc|ccc|ccc|}
\cline { 2 - 10 } & \multicolumn{2}{|c|}{ Net total social expenditure } & \multicolumn{2}{c|}{ Gross total social expenditure } & \multicolumn{3}{c|}{ Idem, excl. health programs } \\
& Intercept & $\mathrm{X} 1$ & $\mathrm{R}^{2}$ & Intercept & $\mathrm{X} 1$ & $\mathrm{R}^{2}$ & Intercept & $\mathrm{X} 1$ & $\mathrm{R}^{2}$ \\
\hline Non-EU15 & 11.03 & 0.202 & 0.018 & 5.21 & 0.469 & 0.114 & -0.03 & 1.074 & 0.338 \\
& $(1.18)$ & $(0.40)$ & $-(0.091)$ & $(0.58)$ & $(1.08)$ & $(0.015)$ & $(0.00)$ & $(2.15)$ & $(0.265)$ \\
\hline EU15 & 1.75 & $0.742 *$ & 0.447 & 4.60 & 0.521 & 0.281 & 11.84 & 0.351 & 0.109 \\
& $(0.30)$ & $(2.98)$ & $(0.397)$ & $(0.66)$ & $(2.07)$ & $(0.216)$ & $(1.88)$ & $(1.16)$ & $(0.028)$ \\
\hline All 25 & 9.26 & 0.371 & 0.097 & 7.77 & 0.382 & 0.159 & 6.01 & $0.635^{* *}$ & 0.336 \\
countries & $(1.79)$ & $(1.53)$ & $(0.056)$ & $(1.67)$ & $(2.04)$ & $(0.120)$ & $(1.75)$ & $(3.33)$ & $(0.305)$ \\
\hline
\end{tabular}

Notes:

- OLS-regression; t-statistics in parentheses. ** Significant at the .01 level; * significant at .05 level.

- Correlation coefficient $\mathrm{R}^{2}$; adjusted $\mathrm{R}^{2}$ in parentheses

- Selected 25 countries: Australia, Austria, Belgium, Canada, Czech Republic, Denmark, Finland, France, Germany, Iceland, Ireland, Italy, Japan, Korea, Luxembourg, Netherlands, New Zealand, Norway, Poland, Portugal, Slovak Republic, Sweden, Switzerland, the United Kingdom and the United States.

Source: OECD (2008), SOCX (2008), and own calculations

A2: CORRELATION TESTS ON SOCIAL PROGRAMS: LINKAGES BETWEEN POVERTY RATES OF AGE GROUPS (LIS PL 60) AND GROSS PUBLIC AND GROSS PRIVATE SOCIAL SPENDING, 2001-2005

\begin{tabular}{l|ccc|ccc|}
\cline { 2 - 7 } & \multicolumn{3}{c|}{ Family programs } & \multicolumn{3}{c|}{$\begin{array}{c}\text { Old age pension programs and } \\
\text { survivors schemes }\end{array}$} \\
& Intercept & $\mathrm{X} 1$ & $\mathrm{R}^{2}$ & Intercept & $\mathrm{X} 1$ & $\mathrm{R}^{2}$ \\
\hline Non-EU15 & $30.098^{* *}$ & $-5.624^{*}$ & 0.499 & $36.812^{*}$ & -1.376 & 0.147 \\
& $(7.74)$ & $(-2.82)$ & $(0.437)$ & $(3.30)$ & $(-1.10)$ & $(0.025)$ \\
\hline EU15 & $22.121^{* *}$ & -2.187 & 0.117 & $45.738^{* *}$ & -1.784 & 0.184 \\
& $(4.91)$ & $(-1.26)$ & $(0.044)$ & $(3.81)$ & $(-1.64)$ & $(0.115)$ \\
\hline All 24 countries & $26.585^{* *}$ & $-3.870^{* *}$ & 0.322 & $38.788^{* *}$ & -1.295 & 0.127 \\
& $(9.43)$ & $(-3.23)$ & $(0.291)$ & $(5.11)$ & $(-1.75)$ & $(0.086)$ \\
\hline
\end{tabular}

Notes:

- OLS-regression; t-statistics in parentheses. ** Significant at the .01 level; * significant at .05 level.

- Correlation coefficient $\mathrm{R}^{2}$; adjusted $\mathrm{R}^{2}$ in parentheses

- Selected 24 countries: Australia, Austria, Belgium, Canada, Czech Republic, Denmark, Finland, France, Germany, Greece, Hungary, Ireland, Italy, Luxembourg, Mexico, Netherlands, Norway, Poland, Slovak Republic, Spain, Sweden, Switzerland, the United Kingdom and the United States.

Source: LIS (2009), SOCX (2008), and own calculations 


\section{A3: TARGETING EFFECT OF SOCIAL EXPENDITURES ON POVERTY REDUCTION (Eurostat PL 60) IN THE EU15, OVER TIME}

We present the linkage between the reduction in poverty rates as result of social transfers and taxes, and social expenditure for EU15 countries, with a breakdown by age groups and social programs targeted to those groups. For the social system as a whole, we do not find a significant relationship between (high) levels of social expenditure and (high) antipoverty effects of social transfers and taxes between EU15 countries in case old age pension is included in market income. However, social expenditure variable(s) become(s) significant when pension is counted as transfer income. As a rule of thumb: family programs are pretty well targeted to those children in need, while social expenditures for old age pension programs and survivor schemes do not seem to alleviate poverty among the elderly in Europe. However, we find pretty good fits when pension is considered as a transfer. All results for around 2005-2007 did not alter (that much) the last decade.

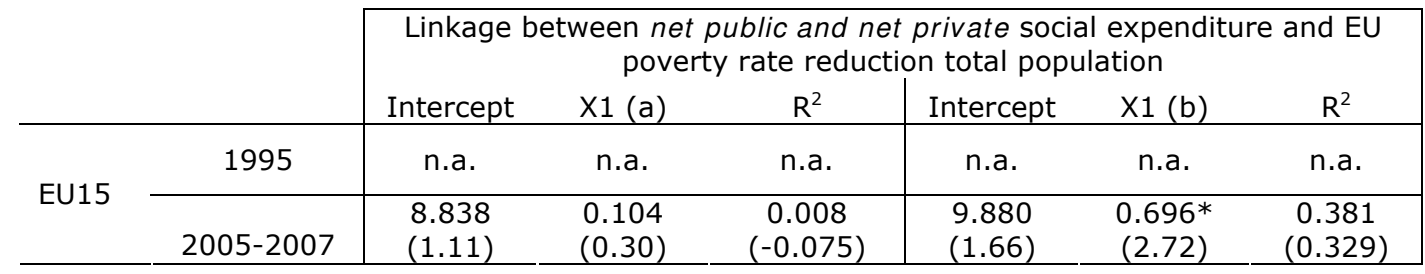

\begin{tabular}{cc|ccc|ccc|}
\cline { 3 - 7 } & & \multicolumn{6}{|c|}{ Linkage between gross total social expenditure and EU poverty rate } \\
& & \multicolumn{5}{c|}{ reduction total population } \\
& & Intercept & $\mathrm{X} 1(\mathrm{a})$ & $\mathrm{R}^{2}$ & Intercept & $\mathrm{X} 1(\mathrm{~b})$ & $\mathrm{R}^{2}$ \\
\hline \multirow{3}{*}{$\mathrm{EU} 15$} & 2.702 & 0.259 & 0.085 & 9.061 & $0.562^{*}$ & 0.375 \\
& \multirow{2}{*}{1995} & $(0.40)$ & $(0.97)$ & $(-0.006)$ & $(1.57)$ & $(2.45)$ & $(0.313)$ \\
\cline { 2 - 7 } & \multirow{2}{*}{$2005-2007$} & -0.962 & 0.435 & 0.166 & 6.368 & $0.715^{* *}$ & 0.562 \\
& $(-0.13)$ & $(1.61)$ & $(0.101)$ & $(1.34)$ & $(4.09)$ & $(0.529)$ \\
\hline
\end{tabular}

\begin{tabular}{|c|c|c|c|c|c|c|c|}
\hline & \multicolumn{6}{|c|}{$\begin{array}{l}\text { Linkage between gross total social expenditure on family programs and } \\
\text { EU poverty rate reduction children }\end{array}$} \\
\hline & & Intercept & $\mathrm{X} 1$ (a) & $\mathrm{R}^{2}$ & Intercept & $\mathrm{X} 1$ (b) & $\mathrm{R}^{2}$ \\
\hline \multirow[b]{2}{*}{ EU15 } & 1995 & $\begin{array}{l}2.903 \\
(1.12)\end{array}$ & $\begin{array}{c}5.798^{* *} \\
(4.06)\end{array}$ & $\begin{array}{c}0.623 \\
(0.585)\end{array}$ & $\begin{array}{c}14.430 \\
(5.48) * *\end{array}$ & $\begin{array}{c}3.465 \\
(2.38)^{*}\end{array}$ & $\begin{array}{c}0.362 \\
(0.298)\end{array}$ \\
\hline & $2005-2007$ & $\begin{array}{l}-0.161 \\
(-0.05)\end{array}$ & $\begin{array}{c}6.213^{* *} \\
(4.82) \\
\end{array}$ & $\begin{array}{c}0.641 \\
(0.614) \\
\end{array}$ & $\begin{array}{l}2.231 \\
(0.72) \\
\end{array}$ & $\begin{array}{c}5.685^{* *} \\
(4.68)\end{array}$ & $\begin{array}{c}0.627 \\
(0.599) \\
\end{array}$ \\
\hline
\end{tabular}

\begin{tabular}{cc|ccc|ccc|}
\cline { 3 - 8 } & & \multicolumn{4}{|c|}{ Linkage between gross total social expenditure for old age pension } \\
& & \multicolumn{4}{c|}{ programs and survivors schemes and EU poverty rate reduction elderly } \\
& Intercept & X1 (a) & $\mathrm{R}^{2}$ & Intercept & X1 (b) & $\mathrm{R}^{2}$ \\
\hline \multirow{3}{*}{ EU15 } & \multirow{2}{*}{1995} & 6.858 & -0.112 & 0.003 & 36.528 & 2.753 & 0.244 \\
& & $(1.14)$ & $(-0.17)$ & $(-0.097)$ & $(2.53)^{*}$ & $(1.80)$ & $(0.169)$ \\
\cline { 3 - 8 } & \multirow{2}{*}{$2005-2007$} & $14.277^{* *}$ & -0.748 & 0.202 & $63.396^{* *}$ & 0.617 & 0.025 \\
& $(3.14)$ & $(-1.82)$ & $(0.141)$ & $(5.39)$ & $(0.58)$ & $(-0.050)$ \\
\hline
\end{tabular}

Notes:

- OLS-regression; t-statistics in parentheses. ** Significant at the .01 level; * significant at .05 level.

- Correlation coefficient $\mathrm{R}^{2}$; adjusted $\mathrm{R}^{2}$ in parentheses

- (a) pensions are excluded from transfers; (b) pensions are included in transfers

- All EU15 countries are included

Source: Eurostat: ECHP/EU-SILC (2009), SOCX (2008), and own calculations 
A4: CORRELATION TEST ON SOCIAL PROGRAMS: LINKAGES BETWEEN POVERTY RATES AND GROSS PUBLIC AND GROSS PRIVATE SOCIAL SPENDING, OVER TIME

Poverty among children: We present the linkage between poverty rates for children (0-17 years) and social expenditure for family programs for all countries where all relevant data items are available. For all data years we find a rather strong negative relationship. This correlation is much stronger for non-EU15 countries compared to the EU15 countries. This finding does not depend on the database used for poverty rates (OECD or LIS), and on the poverty line applied (50 or 60 percent threshold). This finding is rather stable over time.

Panel (a): OECD poverty rates children (PL 50)

\begin{tabular}{|c|c|c|c|c|c|c|c|}
\hline & \multirow{2}{*}{$\begin{array}{l}\text { Family programs, around } 1985 \\
\text { Intercept } \quad \mathrm{X} 1\end{array}$} & \multicolumn{3}{|c|}{ Family programs, around 1995} & \multicolumn{3}{|c|}{ Family programs, around 2005} \\
\hline & & Intercept & $\mathrm{X} 1$ & $\mathrm{R}^{2}$ & Intercept & $\mathrm{X} 1$ & $\mathrm{R}^{2}$ \\
\hline Non-EU15 & & $\begin{array}{l}20.908^{* * *} \\
(6.41)\end{array}$ & $\begin{array}{l}-6.493^{*} \\
(-2.38)\end{array}$ & $\begin{array}{c}0.448 \\
(0.369)\end{array}$ & $\begin{array}{l}22.081 * * \\
(9.75)\end{array}$ & $\begin{array}{c}-4.700 * * \\
(-3.88)\end{array}$ & $\begin{array}{c}0.578 \\
(0.540)\end{array}$ \\
\hline EU15 & & $\begin{array}{c}17.497^{* *} \\
(8.37)\end{array}$ & $\begin{array}{c}-4.156 * * \\
(-4.27)\end{array}$ & $\begin{array}{c}0.584 \\
(0.552)\end{array}$ & $\begin{array}{c}20.293 * * \\
(6.89)\end{array}$ & $\begin{array}{c}-3.927 * * \\
(-3.38)\end{array}$ & $\begin{array}{c}0.468 \\
(0.427)\end{array}$ \\
\hline $\begin{array}{l}\text { All } 28 \\
\text { countries }\end{array}$ & & $\begin{array}{c}18.855^{* *} \\
(11.43)\end{array}$ & $\begin{array}{c}-4.768 * * \\
(-5.35)\end{array}$ & $\begin{array}{c}0.565 \\
(0.545) \\
\end{array}$ & $\begin{array}{c}21.451^{* *} \\
(12.85)\end{array}$ & $\begin{array}{c}-4.374 * * \\
(-5.90)\end{array}$ & $\begin{array}{c}0.572 \\
(0.556)\end{array}$ \\
\hline
\end{tabular}

Panel (b): LIS poverty rates children (PL 60)

\begin{tabular}{|c|c|c|c|c|c|c|c|}
\hline & \multicolumn{3}{|c|}{ Family programs, around 1985} & Family programs, around 1995 & \multicolumn{3}{|c|}{ Family programs, around 2005} \\
\hline & Intercept & $\mathrm{X} 1$ & $\mathrm{R}^{2}$ & Intercept & Intercept & $\mathrm{X} 1$ & $\mathrm{R}^{2}$ \\
\hline Non-EU15 & $\begin{array}{c}30.673 * * \\
(7.64)\end{array}$ & $\begin{array}{c}-12.118^{*} \\
(-3.24)\end{array}$ & $\begin{array}{c}0.724 \\
(0.655)\end{array}$ & & $\begin{array}{c}31.710 * * \\
(6.42)\end{array}$ & $\begin{array}{l}-5.900 \\
(-2.18)\end{array}$ & $\begin{array}{c}0.543 \\
(0.429) \\
\end{array}$ \\
\hline EU15 & $\begin{array}{c}20.704^{* *} * \\
(8.01)\end{array}$ & $\begin{array}{c}-3.842 * * \\
(-3.30)\end{array}$ & $\begin{array}{c}0.475 \\
(0.431)\end{array}$ & & $\begin{array}{c}22.121 * * \\
(4.91)\end{array}$ & $\begin{array}{l}-2.187 \\
(-1.26)\end{array}$ & $\begin{array}{c}0.117 \\
(0.044)\end{array}$ \\
\hline $\begin{array}{l}\text { All } 20 \\
\text { countries }\end{array}$ & $\begin{array}{c}23.646 * * \\
(10.87)\end{array}$ & $\begin{array}{c}-5.166 * * \\
(-4.62)\end{array}$ & $\begin{array}{c}0.543 \\
(0.517) \\
\end{array}$ & & $\begin{array}{c}27.173 * * \\
(8.61)\end{array}$ & $\begin{array}{c}-3.978 * * \\
(-3.02)\end{array}$ & $\begin{array}{c}0.336 \\
(0.299)\end{array}$ \\
\hline
\end{tabular}

Poverty among elderly: Next, we present the linkage between poverty rates for elderly (65 years and over) and social expenditure for old age pension programs and survivors schemes for all countries where all relevant data items are available. There seems to be ample (negative) relationship across all countries. This insignificant correlation is found for both the group of non-EU15 countries and the group of EU15 countries. This finding does not depend on the database used for poverty rates (OECD or LIS), and on the poverty line applied (50 or 60 percent threshold). Also this finding is rather stable over time.

Panel (a): OECD poverty rates elderly (PL 50)

\begin{tabular}{|c|c|c|c|c|c|c|c|}
\hline & \multirow{2}{*}{$\begin{array}{l}\text { Old age pension programs and } \\
\text { survivors schemes, around } 1985 \\
\text { Intercept } \quad \mathrm{X} 1\end{array}$} & \multicolumn{3}{|c|}{$\begin{array}{l}\text { Old age pension programs and } \\
\text { survivors schemes, around } 1995\end{array}$} & \multicolumn{3}{|c|}{$\begin{array}{l}\text { Old age pension programs and } \\
\text { survivors schemes, } 2005\end{array}$} \\
\hline & & Intercept & $\mathrm{X} 1$ & $\mathrm{R}^{2}$ & Intercept & $\mathrm{X} 1$ & $\mathrm{R}^{2}$ \\
\hline Non-EU15 & & $\begin{array}{l}28.746 * * \\
(4.82)\end{array}$ & $\begin{array}{l}-2.198 \\
(-2.18)\end{array}$ & $\begin{array}{c}0.405 \\
(0.320)\end{array}$ & $\begin{array}{l}13.546 \\
(1.72)\end{array}$ & $\begin{array}{l}-0.081 \\
(-0.09)\end{array}$ & $\begin{array}{c}0.001 \\
(-0.09)\end{array}$ \\
\hline EU15 & & $\begin{array}{l}13.649 \\
(1.63)\end{array}$ & $\begin{array}{l}-0.197 \\
(-0.22)\end{array}$ & $\begin{array}{c}0.004 \\
(-0.07)\end{array}$ & $\begin{array}{l}24.506 * * \\
(3.00)\end{array}$ & $\begin{array}{l}-1.121 \\
(-1.51)\end{array}$ & $\begin{array}{c}0.149 \\
(0.084)\end{array}$ \\
\hline $\begin{array}{l}\text { All } 28 \\
\text { countries }\end{array}$ & & $\begin{array}{c}24.006^{* *} \\
(5.68)\end{array}$ & $\begin{array}{l}-1.325^{*} \\
(-2.57) \\
\end{array}$ & $\begin{array}{c}0.231 \\
(0.196)\end{array}$ & $\begin{array}{c}17.260^{* *} \\
(3.29)\end{array}$ & $\begin{array}{l}-0.479 \\
(-0.92)\end{array}$ & $\begin{array}{c}0.031 \\
(-0.01)\end{array}$ \\
\hline
\end{tabular}

Panel (b): LIS poverty rates elderly (PL 60)

\begin{tabular}{|c|c|c|c|c|c|c|c|}
\hline & \multicolumn{3}{|c|}{$\begin{array}{l}\text { Old age pension programs and } \\
\text { survivors schemes, around } 1985\end{array}$} & $\begin{array}{l}\text { Old age pension programs and } \\
\text { survivors schemes, around } 1995\end{array}$ & \multicolumn{3}{|c|}{$\begin{array}{l}\text { Old age pension programs and } \\
\text { survivors schemes, } 2005\end{array}$} \\
\hline & Intercept & $\mathrm{X} 1$ & $R^{2}$ & Intercept & Intercept & $\mathrm{X} 1$ & $\mathrm{R}^{2}$ \\
\hline Non-EU15 & $\begin{array}{c}38.313^{* *} \\
(6.07)\end{array}$ & $\begin{array}{l}-0.081 \\
(-0.08)\end{array}$ & $\begin{array}{c}0.002 \\
(-0.25)\end{array}$ & & $\begin{array}{l}35.119 * \\
(3.36)\end{array}$ & $\begin{array}{l}-0.544 \\
(-0.45)\end{array}$ & $\begin{array}{c}0.047 \\
(-0.19)\end{array}$ \\
\hline EU15 & $\begin{array}{l}42.407 \\
(1.87)\end{array}$ & $\begin{array}{l}-1.505 \\
(-0.63)\end{array}$ & $\begin{array}{c}0.035 \\
(-0.05)\end{array}$ & & $\begin{array}{l}45.738^{* *} \\
(3.81)\end{array}$ & $\begin{array}{l}-1.784 \\
(-1.64)\end{array}$ & $\begin{array}{c}0.184 \\
(0.115)\end{array}$ \\
\hline $\begin{array}{l}\text { All } 20 \\
\text { countries }\end{array}$ & $\begin{array}{l}36.663 * * \\
(4.07)\end{array}$ & $\begin{array}{l}-0.547 \\
(-0.62)\end{array}$ & $\begin{array}{c}0.022 \\
(-0.04)\end{array}$ & & $\begin{array}{l}40.585^{* *} \\
(5.48)\end{array}$ & $\begin{array}{l}-1.290 \\
(-1.81)\end{array}$ & $\begin{array}{c}0.154 \\
(0.107)\end{array}$ \\
\hline
\end{tabular}

Notes:

- OLS-regression; t-statistics in parentheses. ** Significant at the .01 level; * significant at .05 level.

- Correlation coefficient $\mathrm{R}^{2}$; adjusted $\mathrm{R}^{2}$ in parentheses

- Selected 28 countries panel (a): Australia, Austria, Belgium, Canada, Czech Republic, Denmark, Finland, France, Germany, Greece, Hungary, Ireland, Italy, Japan, Luxembourg, Mexico, Netherlands, New Zealand, Norway, Poland, Portugal, Slovak Republic, Spain, Sweden, Switzerland, Turkey, UK and USA.

- Selected 20 countries panel (b): Australia, Austria, Belgium, Canada, Denmark, Finland, France, Germany, Greece, Ireland, Italy, Luxembourg, Mexico, Netherlands, Norway, Spain, Sweden, Switzerland, UK and USA.

Source: LIS (2009), OECD (2008), SOCX (2008), and own calculations 


\section{Research Memorandum Department of Economics}

Research Memoranda

- $\quad$ are available from Department of Economics homepage at : http://www.economie.leidenuniv.nl

- can be ordered at Leiden University, Department of Economics, P.O. Box 9520, 2300 RA Leiden, The Netherlands Phone ++71 527 7756; E-mail: economie@law.leidenuniv.nl

2009.02 Koen Caminada and Kees Goudswaard

Social Expenditure and Poverty Reduction in the EU and other OECD Countries.

2009.01 Maroesjka Versantvoort

Complementariteit in arbeid- en zorgtijd.

2008.06 Koen Caminada and Kees Goudswaard

Effectiveness of poverty reduction in the EU.

2008.05 Koen, Caminada, Kees Goudswaard and Olaf van Vliet Patterns of welfare state indicators in the EU. Is there convergence?

2008.04 Kees Goudswaard and Koen Caminada

The redistributive impact of public and private social expenditure.

2008.03 Karen M. Anderson and Michael Kaeding Pension systems in the European Union: Variable patterns of influence in Italy, the Netherlands and Belgium.

2008.02 Maroesjka Versantvoort

Time use during the life course in USA, Norway and the Netherlands: a HAPC-analysis.

2008.01 Maroesjka Versantvoort

Studying time use variations in 18 countries applying a life course perspective.

2007.06 Olaf van Vliet and Michael Kaeding

Globalisation, European Integration and Social Protection - Patterns of Change or Continuity?

2007.05 Ben van Velthoven

Kosten-batenanalyse van criminaliteitsbeleid. Over de methodiek in het algemeen en Nederlandse toepassingen in het bijzonder.

2007.04 Ben van Velthoven

Rechtseconomie tussen instrumentaliteit en normativiteit.

2007.03 Guido Suurmond

Compliance to fire safety regulation. The effects of the enforcement strategy.

2007.02 Maroesjka Versantvoort Een schets van de sociaal-economische effecten van verlof en de beleidsmatige dilemma's die daaruit volgen.

2007.01 Henk Nijboer

A Social Europe: Political Utopia or Efficient Economics? An assessment from a public economic approach.

2006.04 Aldo Spanjer

European gas regulation: A change of focus.

2006.03 Joop de Kort and Rilka Dragneva

Russia's Role in Fostering the CIS Trade Regime.

2006.02 Ben van Velthoven

Incassoproblemen in het licht van de rechtspraak.

2006.01 Jurjen Kamphorst en Ben van Velthoven

De tweede feitelijke instantie in de belastingrechtspraak.

2005.03 Koen Caminada and Kees Goudswaard Budgetary costs of tax facilities for pension savings: an empirical analysis.

2005.02 Henk Vording en Allard Lubbers How to limit the budgetary impact of the European Court's tax decisions? 
2005.01 Guido Suurmond en Ben van Velthoven

Een beginselplicht tot handhaving: liever regels dan discretionaire vrijheid.

2004.04 Ben van Velthoven en Marijke ter Voert Paths to Justice in the Netherlands. Looking for signs of social exclusion.

2004.03 Guido Suurmond Brandveiligheid in de horeca. Een economische analyse van de handhaving in een representatieve gemeente.

2004.02 Kees Goudswaard, Koen Caminada en Henk Vording Naar een transparanter loonstrookje?

2004.01 Koen Caminada and Kees Goudswaard Are public and private social expenditures complementary?

2003.01 Joop de Kort De mythe van de globalisering. Mondialisering, regionalisering of gewoon internationale economie?

2002.04 Koen Caminada en Kees Goudswaard Inkomensgevolgen van veranderingen in de arbeidsongeschiktheidsregelingen en het nabestaandenpensioen.

2002.03 Kees Goudswaard Houdbare solidariteit.

2002.02 Ben van Velthoven Civiele en administratieve rechtspleging in Nederland 1951-2000; deel 1: tijdreeksanalyse.

2002.01 Ben van Velthoven Civiele en administratieve rechtspleging in Nederland 1951-2000; deel 2: tijdreeksdata.

2001.03 Koen Caminada and Kees Goudswaard International Trends in Income Inequality and Social Policy.

2001.02 Peter Cornelisse and Kees Goudswaard On the Convergence of Social Protection Systems in the European Union.

2001.01 Ben van Velthoven

De rechtsbijstandsubsidie onderzocht. En hoe nu verder?

2000.01 Koen Caminada

Pensioenopbouw via de derde pijler. Ontwikkeling, omvang en verdeling van premies lijfrenten volgens de Inkomensstatistiek.

1999.03 Koen Caminada and Kees Goudswaard Social Policy and Income Distribution. An Empirical Analysis for the Netherlands.

1999.02 Koen Caminada

Aftrekpost eigen woning: wie profiteert in welke mate? Ontwikkeling, omvang en verdeling van de hypotheekrenteaftrek en de bijtelling fiscale huurwaarde.

1999.01 Ben van Velthoven and Peter van Wijck Legal cost insurance under risk-neutrality.

1998.02 Koen Caminada and Kees Goudswaard Inkomensherverdeling door sociale zekerheid: de verdeling van uitkeringen en premieheffing in 1990 en 1995.

1998.01 Cees van Beers

Biased Estimates of Economic Integration Effects in the Trade Flow Equation.

1997.04 Koen Caminada and Kees Goudswaard

Distributional effects of a flat tax: an empirical analysis for the Netherlands.

1997.03 Ernst Verwaal

Compliance costs of intra-community business transactions. Magnitude, determinants and policy implications.

1997.02 Julia Lane, Jules Theeuwes and David Stevens

High and low earnings jobs: the fortunes of employers and workers.

1997.01 Marcel Kerkhofs and Maarten Lindeboom

Age related health dynamics and changes in labour and market status. 
1996.07 Henk Vording

The case for equivalent taxation of social security benefits in Europe.

1996.06 Kees Goudswaard and Henk Vording

Is harmonisation of income transfer policies in the European Union feasible?

1996.05 Cees van Beers and Jeroen C.J.M. van den Bergh

The impact of environmental policy on trade flows: an empirical analysis.

1996.04 P.W. van Wijck en B.C.J. van Velthoven

Een economische analyse van het Amerikaanse en het continentale systeem van proceskostentoerekening.

1996.03 Arjan Heyma

Retirement and choice constraints: a dynamic programming approach.

1996.02 B.C.J. van Velthoven en P.W. van Wijck

De economie van civiele geschillen; rechtsbijstand versus no cure no pay.

1996.01 Jan Kees Winters

Unemployment in many-to-one matching models.

1995.05 Maarten Lindeboom and Marcel Kerkhofs

Time patterns of work and sickness absence. Unobserved effects in a multi-state duration model.

1995.04 Koen Caminada en Kees Goudswaard

De endogene ontwikkeling van de belastingdruk: een macro-analyse voor de periode 19601994.

1995.03 Henk Vording and Kees Goudswaard

Legal indexation of social security benefits: an international comparison of systems and their effects.

1995.02 Cees van Beers and Guido Biessen

Trade potential and structure of foreign trade: the case of Hungary and Poland.

1995.01 Isolde Woittiez and Jules Theeuwes

Well-being and labour market status.

1994.10 K.P. Goudswaard

Naar een beheersing van de Antilliaanse overheidsschuld.

1994.09 Kees P. Goudswaard, Philip R. de Jong and Victor Halberstadt

The realpolitik of social assistance: The Dutch experience in international comparison.

1994.08 Ben van Velthoven

De economie van misdaad en straf, een overzicht en evaluatie van de literatuur.

1994.07 Jules Theeuwes en Ben van Velthoven

De ontwikkeling van de criminaliteit in Nederland, 1950-1990: een economische analyse.

1994.06 Gerard J. van den Berg and Maarten Lindeboom

Durations in panel data subject to attrition: a note on estimation in the case of a stock sample.

1994.05 Marcel Kerkhofs and Maarten Lindeboom

Subjective health measures and state dependent reporting errors.

1994.04 Gerard J. van den Berg and Maarten Lindeboom

Attrition in panel data and the estimation of dynamic labor market models.

1994.03 Wim Groot

Wage and productivity effects of enterprise-related training.

1994.02 Wim Groot

Type specific returns to enterprise-related training.

$1994.01 \quad$ Marcel Kerkhofs

A Quadratic model of home production decisions. 